\title{
Abhandlung
}

Robert Hofmann*, Aleksandar Medović, Martin Furholt, Ildiko Medović, Tijana Stanković Pešterac, Stefan Dreibrodt, Sarah Martini, Antonia Hofmann

\section{Late Neolithic multicomponent sites of the Tisza region and the emergence of centripetal settlement layouts}

https://doi.org/10.1515/pz-2019-0003

Zusammenfassung: In der Theiß-Region an der nördlichen Peripherie der südosteuropäischen Tellkulturen beobachten wir zwischen 5300 und 4450 v. u. Z. das Auftreten großer bevölkerungsreicher Siedlungen, die durch die Kombinationen unterschiedlicher Siedlungskomponenten, von Tells, Flachsiedlungen und Kreisgrabenanlagen gekennzeichnet sind. In diesem Beitrag ist die Entwicklung einer solchen Mehrkomponenten-Siedlung - Borđoš in der serbischen Vojvodina - rekonstruiert, basierend auf geophysikalischen Untersuchungen, Ausgrabungen, systematischen Oberflächenbegehungen und ${ }^{14} \mathrm{C}$-Datierungen. Zwischen 4850 und 4700 v. u. Z. wurde in Borđoš eine bereits länger existierende Tellsiedlung durch eine große Flachsiedlung ergänzt oder zeitweise ersetzt. Im Kontext ähnlicher Fundstellen aus dem Theiß-Gebiet und

*Corresponding author: Robert Hofmann, Kiel University, Institute for Prehistoric and Protohistoric Archaeology; CRC 1266 "Scales of Transformation - Human-Environmental Interaction in Prehistoric and Archaic Societies", Kiel, Germany.

E-Mail: robert.hofmann@ufg.uni-kiel.de

Aleksandar Medović, Museum of Vojvodina Novi Sad, Department of Archaeology, Novi Sad, Serbia.

E-Mail: aleksandar.medovic@muzejvojvodine.org.rs

Martin Furholt, University of Oslo, Department of Archaeology, Conservation and History, Oslo, Norway.

E-Mail: martin.furholt@iakh.uio.no

Ildiko Medović, Novi Sad, Serbia. E-Mail: ildicom2@gmail.com

Tijana Stanković Pešterac, Museum of Vojvodina Novi Sad,

Department of Archaeology, Novi Sad, Serbia.

E-Mail: tijana.pesterac@muzejvojvodine.org.rs

Stefan Dreibrodt, Kiel University, Institute for Ecosystem Research; CRC 1266 „Scales of Transformation - Human-Environmental Interaction in Prehistoric and Archaic Societies”, Kiel, Germany. E-Mail: sdreibrodt@ecology.uni-kiel.de

Sarah Martini, Yale University, Department of Anthropology, New Haven, USA. E-Mail: sjmartini16@gmail.com

Antonia Hofmann, University of Applied Science Berlin,

School of Design and Culture, Berlin, Germany.

E-Mail: Antonia.Hofmann@HTW-Berlin.de darüber hinaus interpretieren wir diese Dynamik als Ausdruck eines zeitweise verstärkten überregionalen Trends zu Bevölkerungsagglomeration zwischen etwa 4900 und 4700 v. u. Z. Hinsichtlich der Entwicklung von Tellsiedlungen und Flachsiedlungen zeichnen sich innerhalb des Theiß-Gebietes erhebliche regionale Unterschiede ab: Im südlichen Teil des Untersuchungsgebietes bilden Tells häufig die Keimzelle später wachsender komplexer Siedlungen. Dagegen stellen im Norden eher große Flachsiedlungen den Ausgangspunkt großer Siedlungen dar. Tells repräsentieren hier entweder räumliche Separierungen mit speziellen Funktionen oder stellen das Ergebnis einer länger andauernden Besiedlung in einem kleinen Teil der ursprünglichen Siedlungsfläche dar. Diese Größenreduzierung von Siedlungen oder teils ihre komplette Auflassung verstehen wir als Teil eines im Karpatenbecken und dem westlichen Balkan weiträumig sichtbaren Trends hin $\mathrm{zu}$ erheblich geringeren Bevölkerungsdichten und räumlich stärker verteilten Siedlungen, der nach 4700 v. u. Z. einsetzte.

Aus Tells- und Flachsiedlungskomponenten bestehende Großsiedlungen der Theiß-Region zeichnen sich durch eine große Diversität hinsichtlich ihrer Größe und räumlichen Konfiguration aus. In Borđoš beobachten wir das Auftreten eines in der Region bisher unbekannten zentripetalen Siedlungslayouts, in dem die Häuser auf einen zentralen Platz im Zentrum der Siedlung ausgerichtet sind. Wir interpretieren die neuartige Siedlungskonfiguration als das Ergebnis des Zusammenschlusses einer im Hinblick auf kulturellen Hintergrund, Identitäten und Netzwerkeinbindung sehr heterogenen Bevölkerung. Demnach können wir die Gruppierung der Häuser um einen zentralen Platz als Ausdruck einer sozialen Organisation verstehen, die in stärkerem Maße als bei Siedlungen mit parallelen Hausreihen auf der Aushandlung kommunaler Belange beruhte.

Schlüsselworte: Theiß-Region, Spätneolithikum, ArchäoMagnetik, ${ }^{14} \mathrm{C}$-Chronologie, Tells, Flachsiedlungen, Kreisgrabenanlagen, Mehrkomponenten-Siedlungen, Bevöl- 
kerungsagglomeration, zentripetales Siedlungslayout, soziale Organisation.

Résumé: Dans la région de la Tisza, au nord des cultures avec des tells typiques du sud-est de l'Europe, de vastes habitats ont été créés, caractérisés par la combinaison de divers composants: des tells, des habitats plats et des espaces clôturés avec tranchées entre 5300 et 4450 ans av. J.-C. Dans cet article, nous avons essayé de reconstruire un site archéologique complexe, Bordjos en Voïvodine (République de Serbie), basé sur des recherches géophysiques, des fouilles, une collection systématique de découvertes en surface et une datation avec la méthode C14. Entre 4850 et 4700 av. J.-C., la localisation d'origine du tell a été étendue ou temporairement remplacé par un habitat plat. Dans le contexte de découvertes similaires dans la région plus large du bassin de la rivière Tisza, on remarque la tendance de l'agglomération croissante de la population entre 4900 et 4700 av. J.-C. Cependant, les deux composants de ce phénomène: un tell et un habitat plat, montrent des modèles de développement différents dans certaines régions. Au sud de la zone explorée, les tells représentent les noyaux initials des grands habitats composants. $\mathrm{Au}$ contraire de cela, au nord, les grands habitats plats ont tendance à représenter le point de départ de l'agglomération de la population locale. Les tells représentent des emplacements séparés avec des fonctions spéciales, ou représentent des habitats initials et plus petits qui se sont développés pour devenir des habitats plats. L'abandon complet ou la réduction de la taille de l'habitats après 4700 av. J.-C. est considéré comme partie d'une tendance qui conduit à une densité de population beaucoup plus faible et à des habitats dispersés dans le bassin des Carpates et dans la région des Balkans occidentaux. Les habitats multicomposants de la région de la Tisza se caractérisent par une grande diversité de taille et de configuration spatiale. À Bordjos, on voit l'occurance d'un plan complètement nouveau et centripète de l'habitat, qui contraste avec la disposition précédemment établie des maisons en lignes parallèles. Ce nouveau phénomène est interprété comme le résultat d'un environnement sociopolitique caractérisé par la coexistence de populations hétérogènes en termes de contexte culturel, d'identité et de connexion à des réseaux de communication et d'échange. Ainsi, un nouvel arrangement d'habitat, caractérisé par un arrangement presque circulaire de maisons autour de l'espace central ouvert, devrait être compris comme l'expression d'une organisation sociale concentre sur la résolution des problèmes communs par le biais de conversations des habitants.
Mots clés: région de la Tisza, néolithique tardif, archéomagnétométrie, datation ${ }^{14} \mathrm{C}$, tells, habitats plats, espaces circulaire, agglomération de population, habitats multicomposants, arrangement centripète d'habitat, organisation sociale.

Abstract: In the Tisza region, at the northern periphery of the tell cultures, large settlements characterised by combinations of tells, flat settlements, and enclosures emerged between 5300-4450 BCE. Here, the development of one such site, Borđoš in the Serbian Vojvodina, is reconstructed based on geophysical surveys, excavations, systematic surface collections, and ${ }^{14} \mathrm{C}$ dating. Between 4850 and 4700 $\mathrm{BCE}$, the original tell site was complemented or temporarily replaced by a large flat settlement. This development is known from a number of similar sites in the region and is discussed as a trans-regional phenomenon of accelerated population agglomeration in the period between roughly 4900 and 4700 BCE. However, the two components of this phenomenon, the tell site and the connected extended flat settlement, show different development trajectories according to sub-region. In the southern part of the study area, tells represent the core of emerging large multicomponent sites. Contrastingly, in the north, large flat settlements tend to be the starting point of local population agglomerations, and tells represent spatially separated locations with special functions or were the result of a particular part of the larger flat settlements experiencing a longer duration of occupation. The complete abandonment and reduction in size of settlements after 4700 BCE is understood in the context of a transregional trend towards settlement dispersal and population decline in the Carpathian Basin and the whole western Balkans.

Multicomponent sites in the Tisza region are characterised by a great diversity in terms of size and spatial configuration. In Borđoš we observe the emergence of a completely new centripetal settlement layout which contrasts with the previously established arrangement of houses in parallel rows. This new phenomenon is interpreted as an outcome of a socio-political environment which was characterised by the cohabitation of a heterogeneous population in terms of cultural background, identity, and connections to networks of communication and exchange. Thus, the new settlement layout, which is characterised by a nearly circular arrangement of houses around a central open space, should be understood as an expression of a social organisation focused on the negotiation of communal concerns.

Keywords: Tisza Region, Late Neolithic, archaeo-magnetometry, ${ }^{14} \mathrm{C}$ chronology, tells, flat settlements, circular enclo- 
sure, population agglomeration, multicomponent settlements, centripetal settlement layout, social organisation.

\section{Introduction}

The first emergence of large aggregated and concentrated villages with several hundreds of inhabitants represents a significant social transformation of Neolithic communities in Southeast Europe and the Carpathian Basin. While preceded by similar phenomena in the Near East and Anatolia millennia earlier ${ }^{1}$, the phenomenon we focus on here is to be understood first and foremost against the regional background of many centuries of small-scale and dispersed settlements during the Early Neolithic ${ }^{2}$. The emergence of tell settlements and large, concentrated settlements had far-reaching consequences for the economic and social configuration of the communities involved. Major preconditions for these agglomeration processes were rapid population growth in the context of the Neolithic Demographic Transition ${ }^{3}$ and an increased degree of sedentism most probably connected to the economic background of mixed, labour-intensive subsistence with intensive garden cultivation and livestock breeding ${ }^{4}$. Also ideological reasons are likely to have played a role both for the creation of tell settlements and for the tendency to concentrate populations. While the emergence of tell settlements was caused by a tendency to value and thus establish spatial permanence, the formation of settlement mounds is connected to the combination of clay-intensive forms of architecture and high building densities ${ }^{5}$. The inhabitants of such densely populated settlements had to accept severe social consequences, like a high degree of communal integration and social monitoring, together with other significant drawbacks such as scalar stress ${ }^{6}$, intra-site pollution, and more exposure to infectious diseases. On the other hand, they might have been drawn to a higher degree of security and shared risks, more intensive and probably richer social relations, more pronounced group identity, and the already mentioned ideological benefit of holding closer relationships to their ancestors ${ }^{7}$.

1 Kuijt 2000; Hodder 2014.

2 e. g. Sherratt 1982, 1983; Nandris 2007; Parkinson/Gyucha 2012.

3 Bocquet-Appel/Bar-Yosef 2008; Müller 2013; Shennan et al. 2013; Porčić et al. 2016.

4 Bogaard 2005; Isaakidou 2011.

5 Chapman 2007; Rosenstock 2009; Duffy et al. 2013.

6 Dunbar 1992; Johnson 1982; Bandy 2004.

7 Chapman 2008.
The Tisza region represents the northern periphery of these Neolithic tell-based communities which were both a latecomer to and never fully integrated in the region. Indeed, in the Tisza region agglomeration processes started around 5300/5200 BCE in the later phase of the Alföld Linear pottery culture. The contemporary emergence of larger settlement concentrations ${ }^{8}$ - albeit more short-lived and showing significantly lower building density than in the Central Balkans ${ }^{9}$ - in Transdanubia parallels this development and in the Central European LBK is connected to this process.

In the catchments of the Tisza and Körös Rivers the circa twenty currently known sites include a combination of Late Neolithic tells, extended flat settlements, enclosures, and associated cemeteries. As many of these settlement forms occur in the same location and appear to have been occupied contemporaneously, these sites must be understood as complex and multicomponent, and are considered by some scholars as focal points of centralised settlement clusters within some kind of tribal organization (Tab. 1, Fig. 1) ${ }^{10}$. In recent decades, intensive research and large-scale rescue excavations in Hungary, Romania, and Serbia have contributed to significantly improve our knowledge of similar complex settlements in the surrounding regions ${ }^{11}$. However, comprehensive reconstructions of their developmental dynamics are nevertheless available only in a couple of exceptional cases.

In this paper we want to explore and discuss a set of interrelated questions which will help us understand the social, economic, and political preconditions and consequences of the concentrated, multicomponent sites of the late $6^{\text {th }}$ millennium in the wider Tisza region. Firstly, we will pursue the question of whether these multicomponent settlements represent a transregional interconnected trend, or if we are dealing with different, convergent phenomena. To do this, we will explore how local site settlement pattern trajectories are related to the transregional evidence of comparable developments of agglomerated sites, how their economies were organised, and how well they were integrated into communication and exchange networks in the Carpathian Basin. Secondly, we will trace the origin and significance of a newly discovered distinctive settlement layout pattern, which we call the centripetal layout and contrast to the linear layout, as we

\footnotetext{
8 Soudský 1962; Makkay 1982; Marton/Oross 2012; Furholt et al. 2014. 9 e. g. Petrasch 2012.

10 Parkinson 2006; Raczky/Füzesi2016.

11 Raczky et al. 2010; Horváth 2005 (2012); Schier 2014; Neumann et al. 2014; Raczky et al. 2015; Marić et al. 2016; Draşovean et al. 2017; Parkinson et al. 2017; Bánffy et al. 2016.
} 
Tab. 1: List of multicomponent sites of the Tisza and Lower Danube region.

\begin{tabular}{|c|c|c|c|c|c|c|c|c|c|}
\hline$\stackrel{⿱ 亠 䒑}{n}$ & 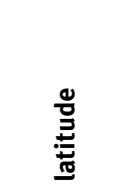 & $\begin{array}{l}\stackrel{0}{\partial} \\
\stackrel{0}{* 0} \\
\frac{0}{0}\end{array}$ & 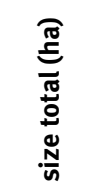 & 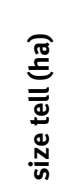 & 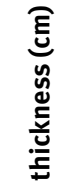 & 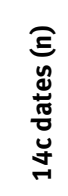 & 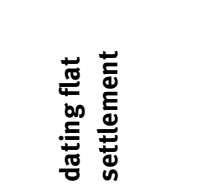 & 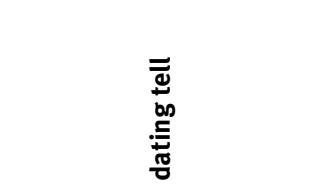 & 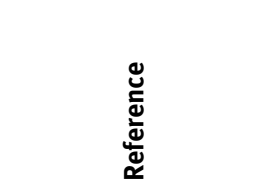 \\
\hline Békés-Povád & 46.7500 & 21.1167 & & & & 0 & & & Neumann et al. 2014 \\
\hline $\begin{array}{l}\text { Berettyóújfalu- } \\
\text { Berta-domb }\end{array}$ & 47.1963 & 21.4854 & & & & 0 & & & Neumann et al. 2014 \\
\hline $\begin{array}{l}\text { Berettyóújfalu- } \\
\text { Herpály }\end{array}$ & 47.2402 & 21.5770 & 15 & 0.3 & 300 & 29 & $\begin{array}{l}\text { Early Tisza/ } \\
\text { Late Szakálhát }\end{array}$ & $\begin{array}{l}4725 \text { or } 4620-4470 \mathrm{cal} \\
\text { BCE }\end{array}$ & $\begin{array}{l}\text { Kalicz/Raczky 1990a; } \\
\text { 1990b }\end{array}$ \\
\hline $\begin{array}{l}\text { Berettyóújfalu- } \\
\text { Szilhalom }\end{array}$ & 47.2167 & 21.5167 & & 0.3 & 180 & 16 & no information & $\begin{array}{l}\text { LBK: c. } 5200-5100 \text { cal } \\
\text { BCE } \\
\text { Late Neolithic: c. } 4700 \\
-4500 \text { cal BCE } \\
\text { Early Copper Age: } \\
\text { c. } 4500 \text { cal BCE }\end{array}$ & Neumann et al. 2014 \\
\hline Borđoš & 45.6000 & 20.1333 & 50 & 7 & 300 & 38 & $\begin{array}{l}4830-4700 \\
\text { cal BC }\end{array}$ & $5000-4515 \mathrm{cal} \mathrm{BC}$ & $\begin{array}{l}\text { Medović et al. } 2014 \text {, } \\
\text { this contribution }\end{array}$ \\
\hline Crna Bara & 45.9574 & 20.3130 & 0.7 & & 330 & 0 & no information & $\begin{array}{l}\text { Vinča B2/C1 } \\
\text { Hiatus } \\
\text { Tiszapolgár }\end{array}$ & Link 2006, $124 \mathrm{f}$. \\
\hline $\begin{array}{l}\text { Dévaványa- } \\
\text { Sártó }\end{array}$ & 47.0333 & 20.9500 & & & 100 & 0 & no information & $\begin{array}{l}\text { ALBK } \\
\text { Szakálhát } \\
\text { Tisza }\end{array}$ & Link 2006, $111 \mathrm{f}$. \\
\hline $\begin{array}{l}\text { Hajdúbö- } \\
\text { szörmény-Pródi- } \\
\text { halom }\end{array}$ & 47.7427 & 21.3406 & 8 & 2.4 & & 0 & Csőszhalom-grou & & Raczky et al. 2010 \\
\hline $\begin{array}{l}\text { Hódmezővásár- } \\
\text { hely-Kökény- } \\
\text { domb }\end{array}$ & 46.3500 & 20.2667 & 21 & 1.5 & 100 & 10 & no information & $\begin{array}{l}\text { Late Szakálhát/Early } \\
\text { Tisza- } \\
\text { Classical Tisza }\end{array}$ & $\begin{array}{l}\text { Link 2006, } 116 \text { f.; } \\
\text { Rosenstock } 2009\end{array}$ \\
\hline Idjoš-Gradište & 45.8537 & 20.3896 & 1.56 & 0.33 & 250 & 0 & $\begin{array}{l}\text { Vinča C/\{D1?]/ } \\
\text { [Classical?] } \\
\text { Tisza }\end{array}$ & $\begin{array}{l}\text { Early Vinča A-B } \\
\text { Vinča C/D1?/[Classical?] } \\
\text { Tisza }\end{array}$ & $\begin{array}{l}\text { Marić et al. 2014; } \\
\text { Mirković-Marić/Marić } \\
2017\end{array}$ \\
\hline $\begin{array}{l}\text { Öcsöd- } \\
\text { Kováshalom }\end{array}$ & 46.8781 & 20.3299 & 21 & $3-5$ & 160 & 16 & Classical Tisza? & $\begin{array}{l}\text { Late Szakálhát/Early } \\
\text { Tisza- } \\
\text { Classical Tisza }\end{array}$ & Raczky, 2009 \\
\hline $\begin{array}{l}\text { Pietrele } \\
\text { I-Magura } \\
\text { Gorgana }\end{array}$ & 44.0678 & 26.1565 & 5 & 0.69 & 900 & 45 & $\begin{array}{l}5150-5050 \mathrm{cal} \\
\text { BCE } \\
4600-4250 \mathrm{cal} \\
\text { BCE }\end{array}$ & $4650-4250$ cal BCE & $\begin{array}{l}\text { Hansen et al., 2012; } \\
\text { Reingruber 2015; } \\
\text { Hansen et al. } 2014 \\
(2017)\end{array}$ \\
\hline $\begin{array}{l}\text { Polgár- } \\
\text { Csőszhalom }\end{array}$ & 47.8667 & 21.1167 & 24 & 2.7 & 400 & 40 & $\begin{array}{l}4900-4680 \mathrm{cal} \\
\mathrm{BCE}\end{array}$ & $4850-4450$ cal. BCE & $\begin{array}{l}\text { Raczky et al. 2015; } \\
\text { Raczky } 2018\end{array}$ \\
\hline $\begin{array}{l}\text { Polgár- } \\
\text { Bosnyákdomb }\end{array}$ & 47.8667 & 21.1167 & 6 & 0.75 & 150 & 7 & $\begin{array}{l}\text { Later [Clas- } \\
\text { sical] Tisza/ } \\
\text { Csőszhalom- } \\
\text { group }\end{array}$ & $\begin{array}{l}\text { ALBK/Bükk + } \\
\text { Csőszhalom, Proto- } \\
\text { Tiszapólgar, } \\
4600-4450 \text { ca. BCE }\end{array}$ & Raczky/Anders 2016 \\
\hline $\begin{array}{l}\text { Sîntana- } \\
\text { Holumb }\end{array}$ & 46.3820 & 21.4632 & 3 & 0.11 & 300 & 0 & no information & $\begin{array}{l}\text { Late Tisza + } \\
\text { Proto-Tiszapolgar }\end{array}$ & Link 2006, 122-123 \\
\hline
\end{tabular}


Tab. 1 (continued)

\begin{tabular}{|c|c|c|c|c|c|c|c|c|c|}
\hline $\begin{array}{l}\text { Szeghalom- } \\
\text { Kovácshalom }\end{array}$ & 47.0167 & 21.1667 & 70 & 0.8 & 380 & 0 & $?-4700 \mathrm{BCE}$ & & Gyucha et al., 2015 \\
\hline $\begin{array}{l}\text { Szegvár-Tüzkö- } \\
\text { ves }\end{array}$ & 46.6167 & 20.2333 & 11 & 3.14 & 200 & 8 & no information & $\begin{array}{l}\text { Early Tisza } \\
\text { Hiatus } \\
\text { Classical Tisza }\end{array}$ & $\begin{array}{l}\text { Link, 2006, 114-116; } \\
\text { Horváth } 2015\end{array}$ \\
\hline $\begin{array}{l}\text { Szentpéter- } \\
\text { szeg-Kovadomb }\end{array}$ & 47.2338 & 21.6231 & $\geq 2.7$ & 0.7 & & 0 & no information & no information & Raczky/Anders 2014 \\
\hline $\begin{array}{l}\text { Tápé-Lebő A } \\
\text { (Felsőhalom) }\end{array}$ & 46.2478 & 20.4112 & 5 & & 250 & 16 & no information & $\begin{array}{l}\text { frühes Szakálhát, Bükk } \\
\text { classical Tisza + late Tisza } \\
\text { Proto-Tiszapolgár }\end{array}$ & $\begin{array}{l}\text { Link 2006, 121; } \\
\text { Rosenstock } 2009\end{array}$ \\
\hline Uivar-Gomila & 45.6483 & 20.8625 & 3 & & 400 & 14 & $\begin{array}{l}?-4500 \mathrm{cal} \\
\mathrm{BCE}\end{array}$ & $5150-4700 \mathrm{cal} \mathrm{BCE}$ & $\begin{array}{l}\text { Schier 2014; } \\
\text { Draşeovan et al. } 2017\end{array}$ \\
\hline
\end{tabular}

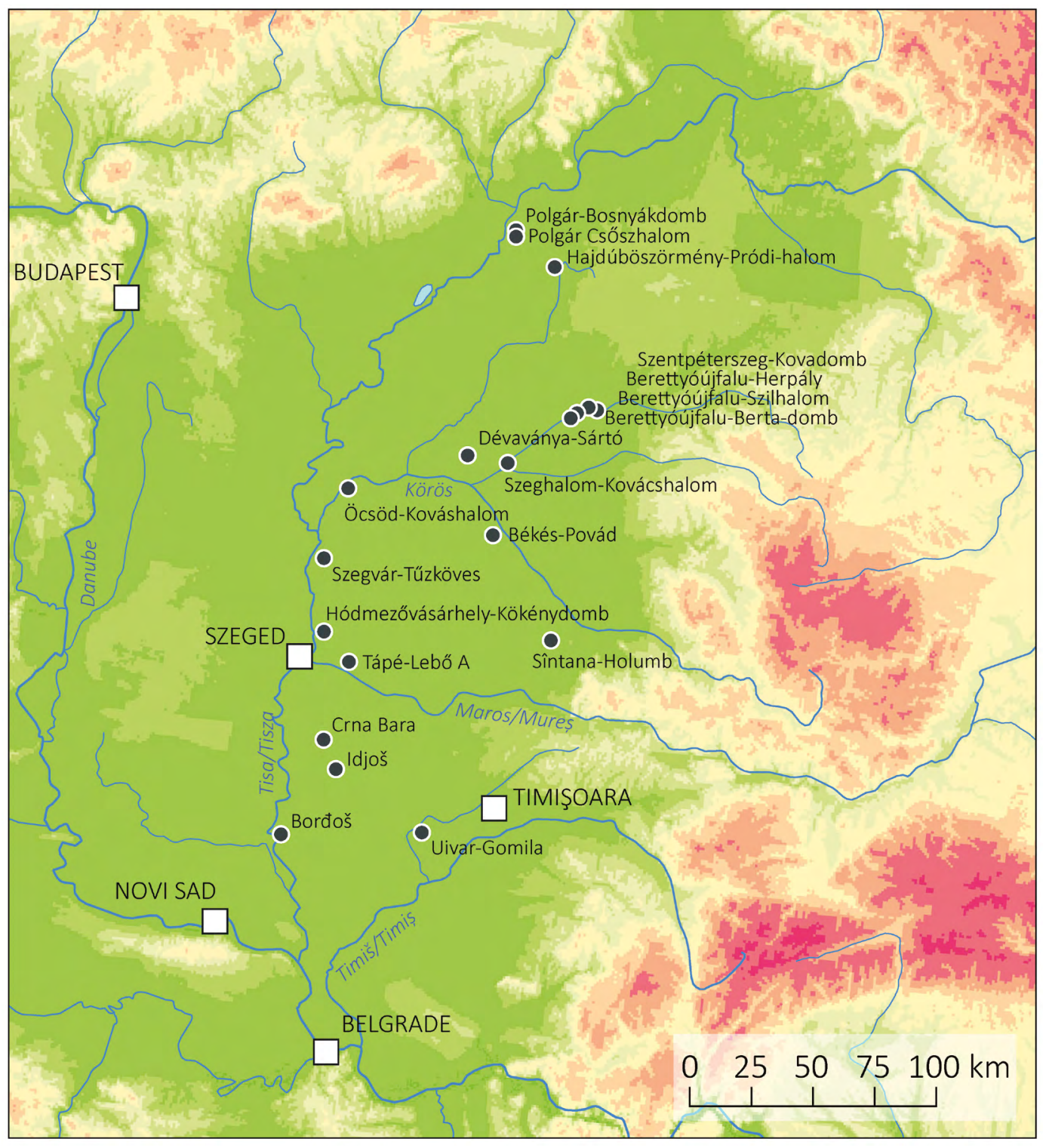

Fig. 1: Spatial distribution of multicomponent sites in the Tisza region (Source: R. Hofmann). 
believe that this holds the clue to a better understanding of regional specifics regarding the social organisation of large settlements. Centripetal settlement layouts are characterised by a circular, or almost circular, arrangement of houses creating a central space in the settlement often left open and unbuilt.

\section{The multicomponent site Borđoš}

To explore these research questions, we start with new data on the spatial layout, internal development, economy, and integration into regional communication and exchange networks from the site of Borđoš. This new data is the result of field work in a micro-region near the modern town Novi Bečej, situated along the Tisza about $30 \mathrm{~km}$ to the north of Novi Sad and the confluence of the Tisza and Danube rivers ${ }^{12}$. There, extensive field work has been carried out on an $11 \mathrm{~km}^{2}$ loess terrace and the surrounding floodplains in an ongoing cooperation between the Museum of Vojvodina Novi Sad and the Christian-Albrecht's University in Kiel. A major focus of this project has been the complex Late Neolithic site Borđoš located in the southwestern part of the terrace which was repeatedly settled between 5100 and 4600 BCE by Early Neolithic (Starčevo-Körös-Criş pottery style), Late Neolithic (Tisza, Vinča pottery styles) and additionally by Late Bronze Age (Gava-Belegiš pottery style) communities.

Our study region is located not only where the different ecological zones of the Carpathian Basin and the low middle mountain range of the Central Balkans meet, but also at the interface of different cultural groups with Vinča and Tisza pottery. The overall goal of our research in Borđoš is to achieve a better understanding of the problem of how settlement and population dynamics operate as drivers of social change and how these processes are interlinked with the transformations in subsistence, social organisation, communication, exchange, and mobility which likely underlie the "hybrid" characteristics of these settlements.

This paper, firstly, provides an overview of the fieldwork conducted since 2014 at the site of Borđoš including excavation, a magnetic survey, and a radiocarbon dating program. On a much broader geographical scale, we then take our new data as a starting point for a wider discussion of the social developments of the known multicomponent sites in the Tisza region.

12 Medović et al. 2014; Stanković-Pešterac et al. 2014.

\section{Geophysical Survey}

In order to gain a complete picture of the Neolithic site of Borđoš we performed a geomagnetic survey over an area of 51 ha using a SENSYS MAGNETO® MX V3 Survey System (SENSYS Sensorik \& Systemtechnologie GmbH Bad Saarow, Germany). Additionally, in two smaller areas of the site electrical resistivity measurements (ERT) were taken (using an ABEM Terrameter SAS 300B): In the tell area the application of this second survey method was meant to help determine the thickness of the anthropogenic deposits. In the flat settlement, the ERT measurements were meant to clarify whether unburned houses existed which were not visible by means of magnetic survey in addition to the numerous burned buildings which were.

The magnetic survey plan can be interpreted as clearly showing four larger Neolithic settlement components. In addition, parts of a Bronze Age settlement and several smaller, partly still unspecified units could be identified (Fig. 2-3):

In the northern part of the site, a settlement mound with two oval ditches is visible. Although the tell covers over 9 ha, 6.9 ha are enclosed within the double-ditch system $^{13}$.

To the southwest of this settlement mound there is a semi-circular rondel-like enclosure composed of two parallel ditches. Today, this structure measures 0.8 ha (enclosed area 0.52 ha), but obviously a large part of the enclosure was lost to lateral erosion of the Tisza towards the formerly existing river bed (today silted up). If it is assumed that the rondel was originally circular, the diameter of the existing structure (135 m, enclosed area $115 \mathrm{~m}$ ) suggests an original size of ca. 1.4 ha with 1 ha inside of the ditches.

In the southern part of the survey area a large flat settlement of 25 ha is enclosed by several rings of ditches. A small mound partly destroyed by a modern building is located in the centre of this area. Lateral erosion of the terrace has also influenced this settlement zone; its original spatial extent is estimated as 38 ha (enclosed area $37 \mathrm{ha}$; diameter $700 \mathrm{~m}$ ). The inner part of the flat settlement enclosed by a set of at least four ditches would have covered around 23 ha (enclosed area 20 ha; diameter $500 \mathrm{~m}$ ).

To the north of the settlement mound, across a drainage channel likely belonging to the Pleistocene, there is a less densely populated area of 3.5 ha with Early Neolithic finds and scattered Late Neolithic houses. In the south there is additionally a large settlement partly overlap-

13 Compare Medović et al. 2014, table I and II. 


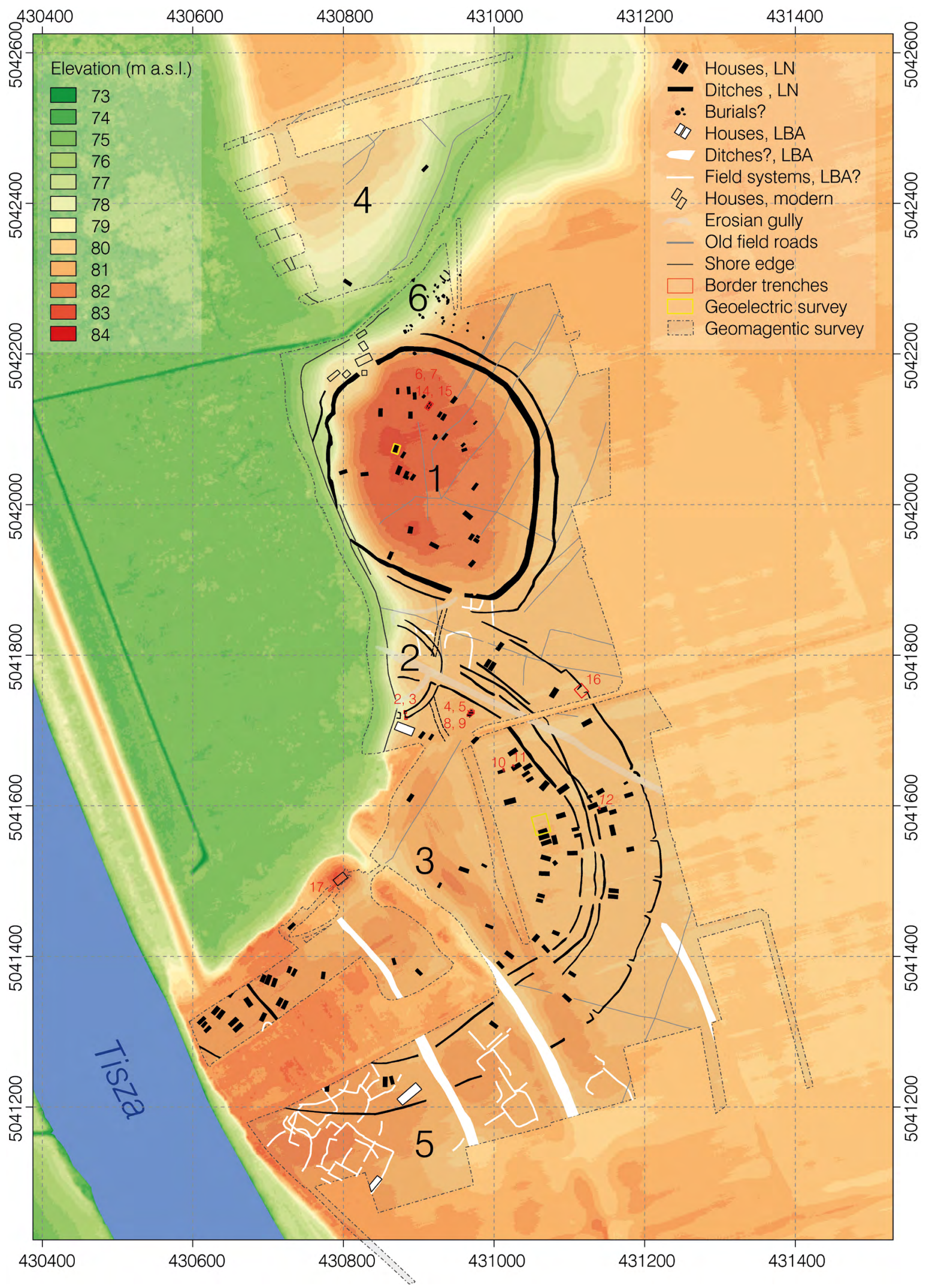

Fig. 2: Borđoš. Interpretative plan of the magnetic survey. The settlement components which are described in the text are marked with black numbers. The red numbers mark the excavation trenches. LN=Late Neolithic, LBA=Late Bronze Age. Base map: SRTM 1 Arc-Second Global. Geodetic system: WGS84 UTM34N (Source: R. Hofmann). 

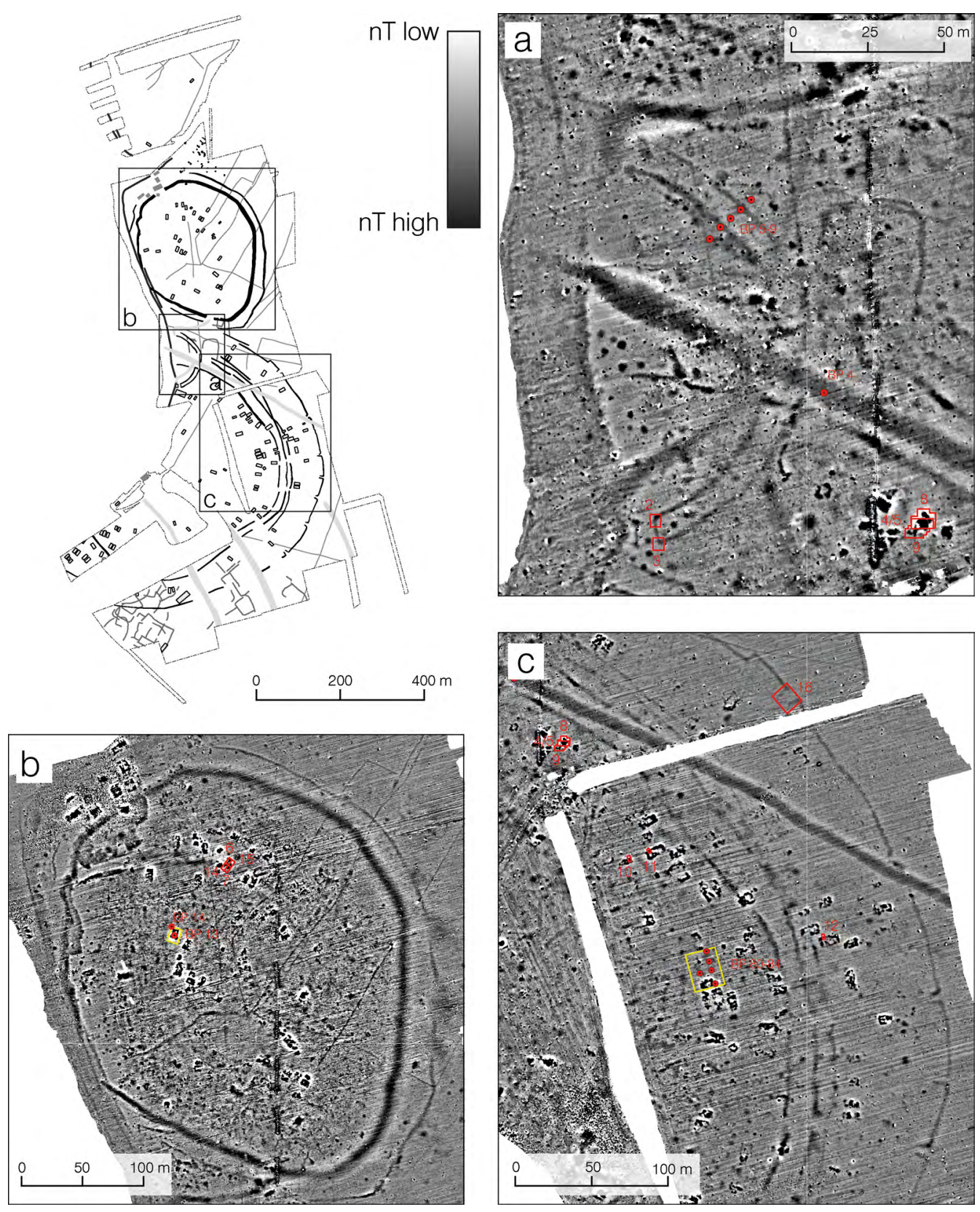

Fig. 3: Borđoš, plan of the magnetic survey with position of trenches, drilling cores, and areas surveyed using electrical resistivity measurements. a) rondel-like circular earthwork; b) enclosure tell settlement and possible cemetery north-east of it; c) north-eastern part of the flat settlement with gates (Source: R. Hofmann).

ping with the Neolithic flat settlement characterized by dispersed large longhouses and field systems with Late Bronze Age Gava ceramics.

To the northeast of the settlement mound, a group of small anomalies is visible which might represent a Neolithic or Late Bronze Age burial place with an area of 0.6 ha.

The main components of the Neolithic settlements are delimited by ditches. The settlement mound is enclosed by an up to $8 \mathrm{~m}$ wide inner ditch and a considerably smaller, $4 \mathrm{~m}$ wide outer ditch. Both ditches seem to have no entrance and are only interrupted by younger disturbances in the north and the west. In contrast, the parallel and considerably narrower ditches of the rondel-like enclosure are interconnected by traversal ditches where a 5-6 m wide interruption in the main ditches is situated in the south (Fig. 3a). In the flat settlement at least four ditches enclose an inner settlement area originally 20 ha size; a single 

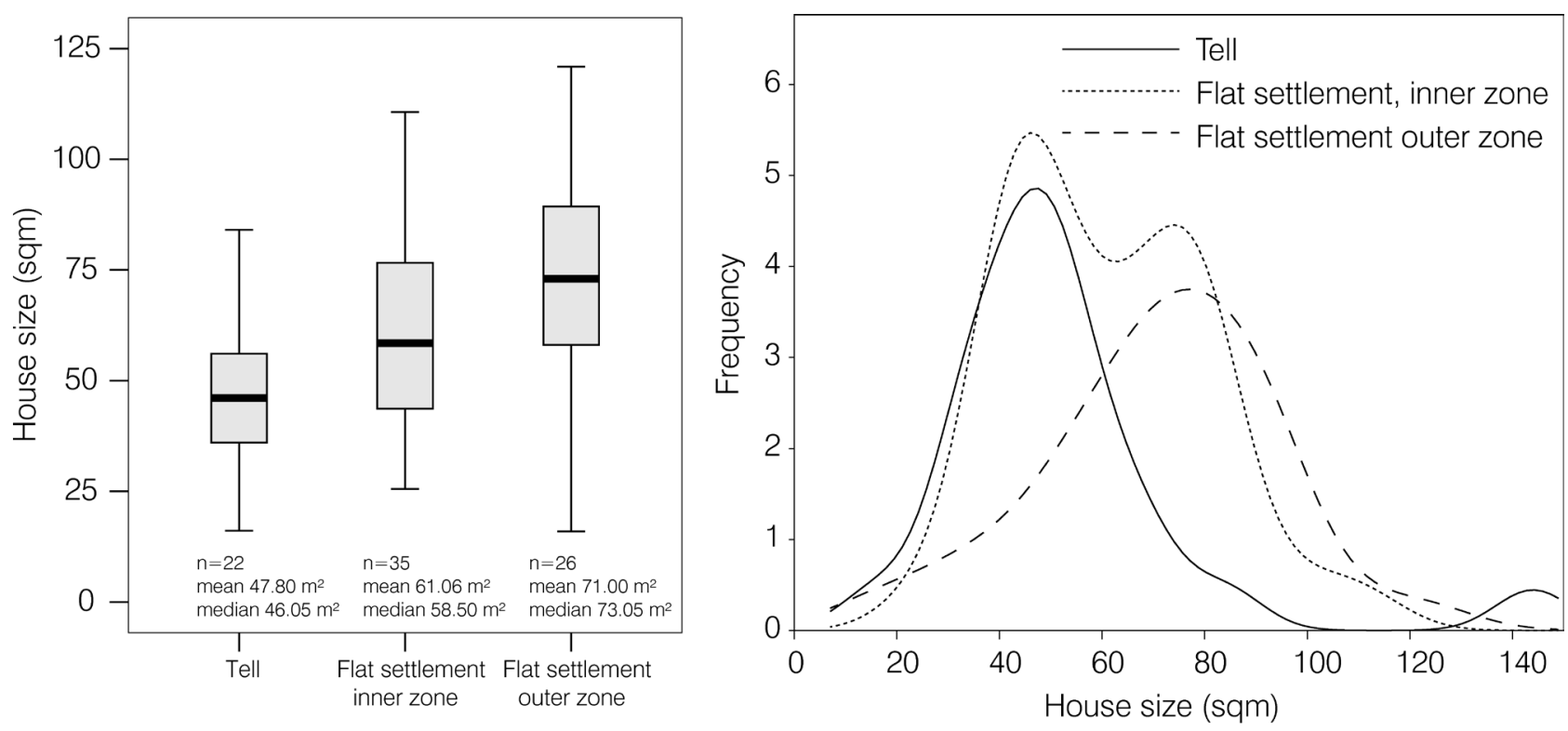

Fig. 4: Borđoš, Comparison of house sizes within the different settlement components: a) Boxplots, b) Kernel density distributions (Source: R. Hofmann).

outer ditch encircled a considerably larger area of 37 ha. Intersections of ditches in the inner bundle suggests that the ditches here were not contemporary, but are the result of repeated re-cuttings.

The ditches of both the inner and the outer enclosure of the flat settlement show interruptions which we interpret as gates (Fig. 3c). This interpretation is particularly well supported in the case of seven discontinuities in the outer ditch whose endings are turned inwardly towards the centre of the settlement. It is remarkable that these gates seem to be restricted to the eastern side of the settlement, while they are lacking in the north and the south. It is quite surprising that no obvious direct connection exists to the adjacent settlement mound. The gates of the outer enclosure ring correspond in at least three cases with interruptions in the inner bundle of ditches. This probably indicates long-lasting continuity of the entrances and the related path system.

Clues regarding the chronological relations of the different settlement parts can be only partly deduced from their spatial relationship in the plan of the magnetic survey. Firstly, the circular enclosure and the flat settlement cannot be completely contemporary since the inner bundle of ditches from the flat settlement run through the area of the enclosure. Secondly, contemporaneity of the settlement mound and the flat settlement cannot be excluded since the outer ditches of the flat settlement and the enclosing ditches of the settlement mound are located very close to each other without touching. The clarification of the temporal relationship of the two settle- ments was only possible by gaining additional evidence from drillings, targeted excavations, and radiocarbon dating.

The part of the flat settlement which is enclosed by the inner bundle of ditches shows a significantly higher density of disturbances represented by magnetic anomalies than the outer zone of the settlement. Most likely this difference can be best explained by a significantly longer occupation of the inner settlement zone.

In total, in the settlement mound and the flat settlement we can identify about 110 characteristic magnetic anomalies derived from burned houses with floor sizes between 15 and $114 \mathrm{~m}^{2}$. Differences regarding size and direction of neighbouring anomalies indicate that not all houses belong to the same construction phase. With regard to the size of house anomalies, there are clear differences between the different zones of the settlement (Fig. 4). The houses in the tell settlement have a median of about 46 $\mathrm{m}^{2}$, in the central part of the flat settlement about $60 \mathrm{~m}^{2}$, and in the outer part of the of the flat settlement $73 \mathrm{~m}^{2}$. A kernel density diagram shows a bimodal distribution for the central part of the flat settlement which might indicate the occurrence of houses from different periods.

The uneven distribution and the clustering of houses in both the flat settlement and the settlement mound suggests that the number of buildings was much higher and that the burning down of houses was due to chance rather than a general rule. Therefore, as evidence from other sites also suggests, we need to take into consideration numerous unburnt buildings which are not visible in the mag- 
netic survey ${ }^{14}$. Perhaps the situation in the southwestern part of the flat settlement gives an impression of the actual building density and building arrangement. There, it is possible to observe groups of two or three houses arranged in parallel rows.

One of the most remarkable observations is the centripetal alignment of the longitudinal axes of the houses towards the settlement centre in both the area of tell settlement and the area of the flat settlement. This is particularly well visible in the area of the flat settlement. Thus, both settlements were organized according to a spatial principle which is so far almost unknown in the Banat and Vojvodina. Hitherto, similarly organized settlements were found exclusively in Transylvania and east of the Carpathian Mountains in Cucuteni-Tripolye settlements of the $4^{\text {th }}$ millennium.

\section{Systematic surface collections, drillings, and excavations}

Based on the findings of the magnetic survey, systematic surface collections, drillings, and targeted excavations were performed during seven field campaigns. The sampling strategy aimed at a systematic comparison of the different settlement components and the establishment of an absolute and relative site chronology. In order to gain reliable information regarding the contextualization of ceramic styles and of economic data, two burnt houses were excavated completely in the flat settlement and the mound (area 3: trenches 4, 5, 8 and 9 and area 4: trenches 6-7, 15-16). Moreover, a total of three test trenches were excavated in houses of different size and location within the flat settlement in order to collect datable material from clear contexts (trenches 10-12). Furthermore, we excavated at the entrance of the rondel-like enclosure (trenches 2-3), in the area of a gate on the east side of the flat settlement (trench 14), and in the small mound which is located in the centre of the flat settlement (trench 17).

Analysis of intra-site find distributions recovered during systematic surface collections show considerable variability regarding surface find densities in the different settlement components. The tell area shows clearly higher find densities than the flat settlement which is most likely due to higher occupation intensity and building density, longer settlement duration, and ongoing erosion processes in the area of the settlement mound. The comparison within the area of the settlement mound reveals lower

14 Hofmann et al. 2006; Tasić et al. 2016; Draşovean et al. 2017. ceramic densities and higher degrees of fragmentation in its central part. We interpret this finding as an indication for the existence of a central unbuilt space since there are also no houses visible in this location in the picture from the magnetic prospection. Analysis of find distributions within the settlement mound furthermore shows concentrations of certain flint raw materials and differentiation between areas with tools and production remains (cores, flakes). Mixed find-assemblages in the southwestern part of the flat settlement reveal a large overlap of the Late $\mathrm{Ne}$ olithic and Late Bronze Age settlements.

Through drillings and electrical resistivity measurements, in the area of the settlement mound we could identify anthropogenic deposits of up to $3 \mathrm{~m}$ thickness ${ }^{15}$. Due to the current high erosion intensity, however, a certain loss of substance from the upper layers cannot be excluded. In contrast, in the area of the flat settlement the conditions of preservation for near-surface features are much better, since here archaeological layers are superimposed by a $35-50 \mathrm{~cm}$ thick humus layer. This difference is responsible for the varying degrees of conservation of the two uncovered houses.

Both excavated houses were post-built constructions; the houses measured 5.6 [?] x $4.0 \mathrm{~m}$ and $9.0 \times 4.5 \mathrm{~m}$ in the flat settlement and the settlement mound respectively. In both cases, the buildings had at least partly slightly elevated and heavily burned platforms. In the case of the house in the flat settlement, an intermediate wall encountered in situ enables the reconstruction of a floor plan with two rooms.

On top of the heavily burned platforms, house inventories of the last phases of use were preserved in situ in primary find contexts. In both fully excavated houses, Vinča (C2/D1 and D1 style) and Tisza (classical style) vessels occur together. Vinča pottery is represented by bowls and amphorae, Tisza pottery in particular by different kinds of bowls. However, it should be emphasized that most of the vessels are undecorated and can, before the completion of analysis, only preliminarily and not unambiguously be assigned to certain pottery styles. Differences between tell and flat settlement ceramics concern inter alia the frequency of styles: While inventories of the flat settlement component tend to show a balanced proportion of Tisza and Vinča pots, Vinča pots clearly dominate in the excavation area of the settlement mound. In the tell area it is possible that Proto-Tiszapolgár pottery also occurs.

Besides the different pottery styles and settlement characteristics, different flint raw materials like obsidian, radiolarites (Mecsek, Bakony), and shiny light grey brown

15 Medović et al. 2014; Stanković Pešterac et al. 2014. 
(Volhynian?) flint as well as Spondylus prove external relations and exchange contacts in different directions. Accordingly, in the tell settlement, obsidian with $38 \%$ of the 883 chipped stone artefacts (including micro-debris) is one of the most frequent stone raw materials, whereas radiolarite represents only $11 \%$, and shiny light grey brown flint $7 \%$ of the assemblage. In contrast, only a total of 28 flint artefacts were found in the flat settlement despite a larger excavation area; in this assemblage there is a significantly lower proportion of obsidian (4\%), and similar proportions of radiolarite (11\%) and shiny light grey flint (7\%). However, a quantitative comparison between tell and flat settlement is difficult because of the low find densities in the flat settlement.

Our investigations at the gate of the rondel-like earthwork showed that the two parallel v-shaped ditches were backfilled in the same event. Consequently, the contemporary existence of the two parallel ditches is highly probable. Daub from the remains of buildings inside of the earthwork was included in the fill of the ditches. However, due to the location of the rondel at the modern edge of the terrace, the Neolithic surface is completely eroded and in situ building remains are not preserved.

\section{Absolute chronology}

Thirty-nine ${ }^{14} \mathrm{C}$ dates mostly obtained from short-lived sample material from drilling cores and excavation areas provide reliable information on the temporo-spatial development of the settlement complex from Borđoš (Tab. 2). These data were calibrated and modelled using the boundary function of the software OxCal 4.3 and the calibration curve INTCAL1 $3^{16}$. The results obtained are displayed in Fig. 6 and summarised in Tab. 3.

According to these models the tell and the circular enclosure clearly represent the earliest settlement components: The oldest samples dated so far came from backfill layers of the ditch of the small earthwork, which was most probably completely backfilled and levelled within a short period between 5025 and $4950 \mathrm{BCE}^{17}$.

The oldest dates from the tell settlement derived from a drilling core situated in the centre of the mound. The deepest dated samples (Poz-63492 and Poz-63493) were

16 Bronk Ramsey 2009; 2017; Reimer et al. 2013.

17 As they clearly deviate from all other dates in our model, we excluded two very old dates (Poz-63490 and Poz-63491) which were obtained from a drilling core directly above the ditch bottom. Since charcoal of oak was used as sample material, old-wood effects are assumed to be responsible for the early dating in the $7^{\text {th }}$ millennium BC. obtained from a layer $2 \mathrm{~m}$ below the modern surface and about $0.75 \mathrm{~m}$ above the tell base. According to these dates, the habitation started in the area of the tell settlement with the highest probability in the time around 4950 BCE when the adjacent earthwork was already levelled. If we additionally take into consideration the settlement deposits below the deepest dated samples, an earlier onset and the simultaneous existence of tell and circular enclosure seems highly likely.

The uppermost levels (about $1 \mathrm{~m}$ thickness) of the tell settlement which correspond to the structures visible in the magnetic survey were excavated in trenches 6, 7,15 and 16. The modelling of six available datings using the boundary function of the OxCal-software suggests the beginning of the last building horizon around 4730 BCE and an end of the tell sedimentation around 4515 BCE. However, in this model the youngest date Poz-90687 shows a poor agreement with the remaining data and the probability of the model amounts to only $79.3 \%$. If this date is excluded from the model, a considerably earlier end of the settlement activity before 4600 BCE is suggested. A similar result is obtained when we include the stratigraphic contexts of the sampled material into our model. When this information is included, however, higher levels of model agreement are only reached by exclusion of the dates Poz-90537 and Poz-90687. Preliminarily, from the point of view of the currently available data, the most probable scenario is that the occupation of tell ended in the last decades of the $47^{\text {th }}$ century BCE.

From the flat settlement, $17{ }^{14} \mathrm{C}$ dates from four excavation areas are available. In this part of the site, settlement activities start after $4850 \mathrm{BCE}$ and end in the most parts before $4700 \mathrm{BCE}$. Younger dates from the $47^{\text {th }}$ century originate exclusively from a deposition of 25 vessels which were placed next to the gate in trench 14 . Most likely these vessels belong to a group of cremation burials which were interred after the flat settlement was already abandoned and the outer ditch of the settlement was levelled.

So far, dates from the tell settlement that clearly fall into the chronological range of occupation of the flat settlement are absent. Therefore, it is still an open question whether the settlement mound was continuously populated or whether the settlement activities were interrupted during the existence of the flat settlement. Attempts to address this question and to test different sedimentation scenarios by means of age-depth models unfortunately failed due to the small sample size. 


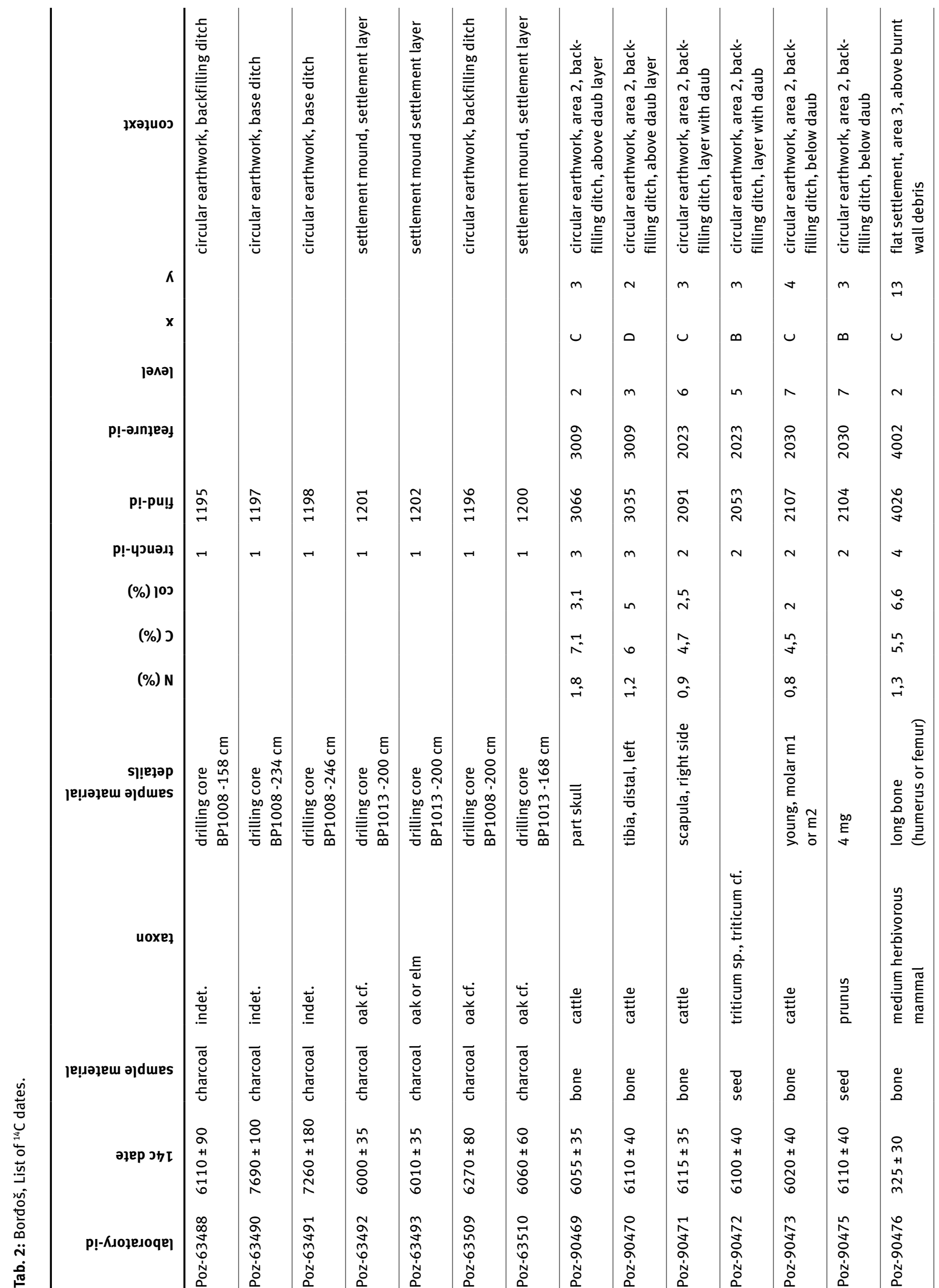




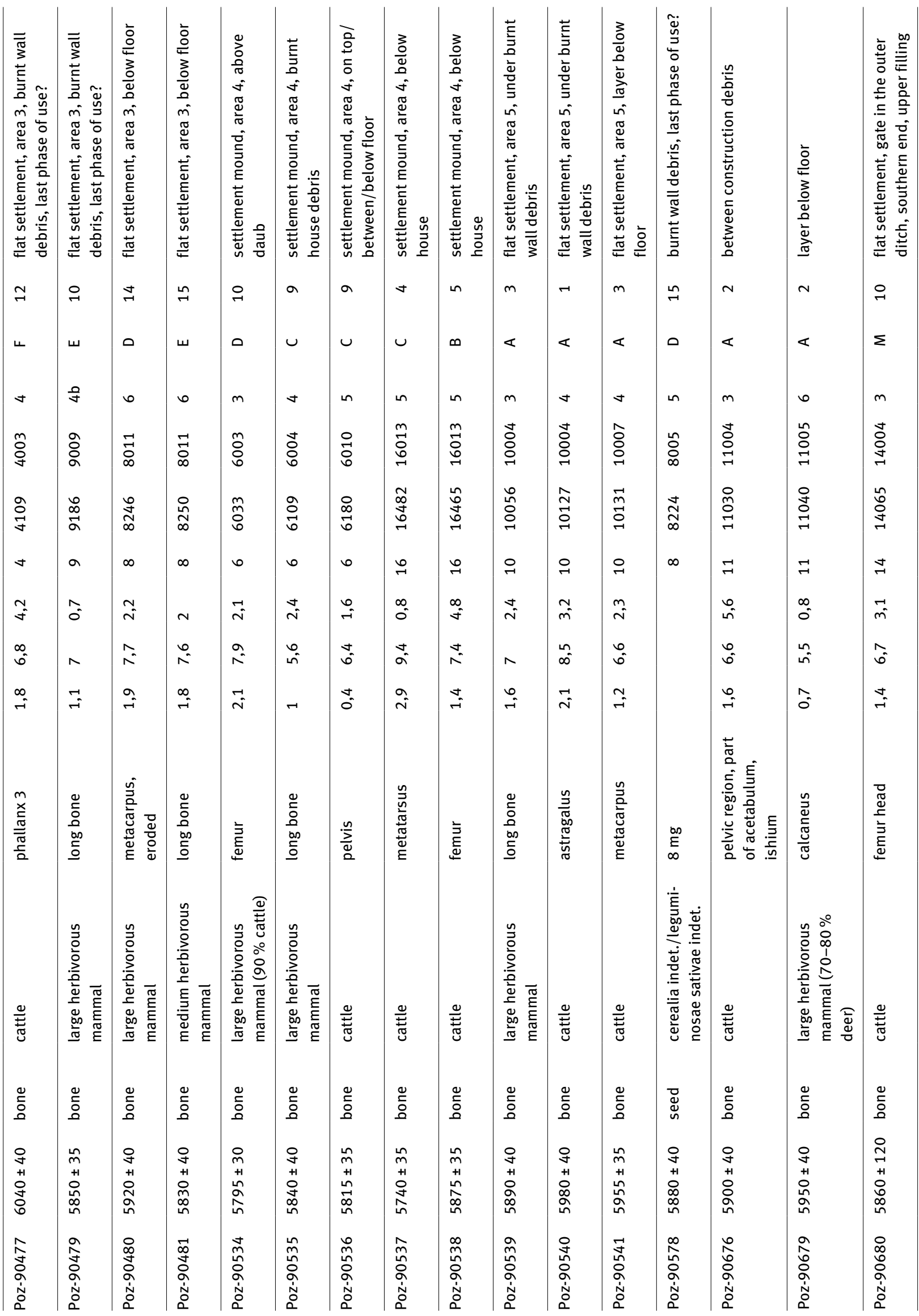




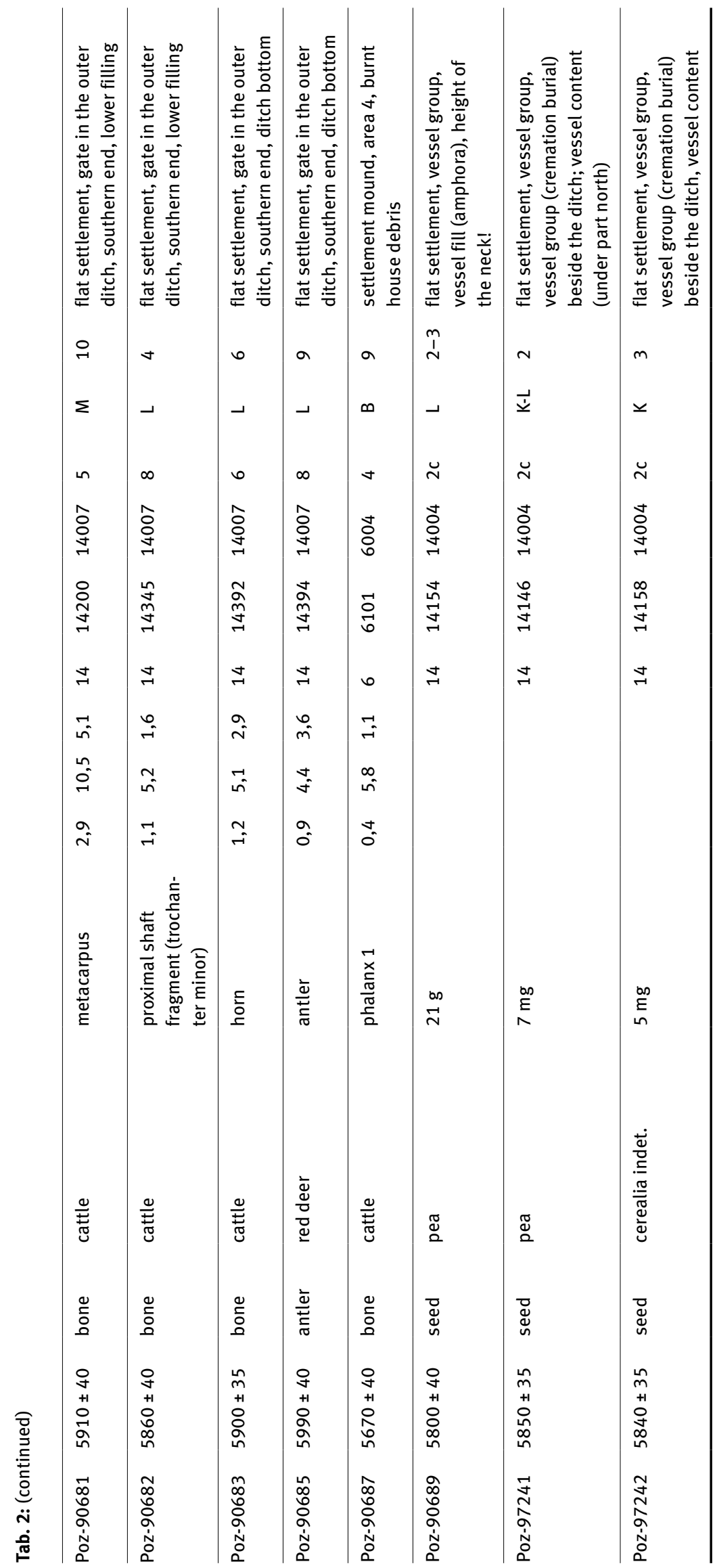




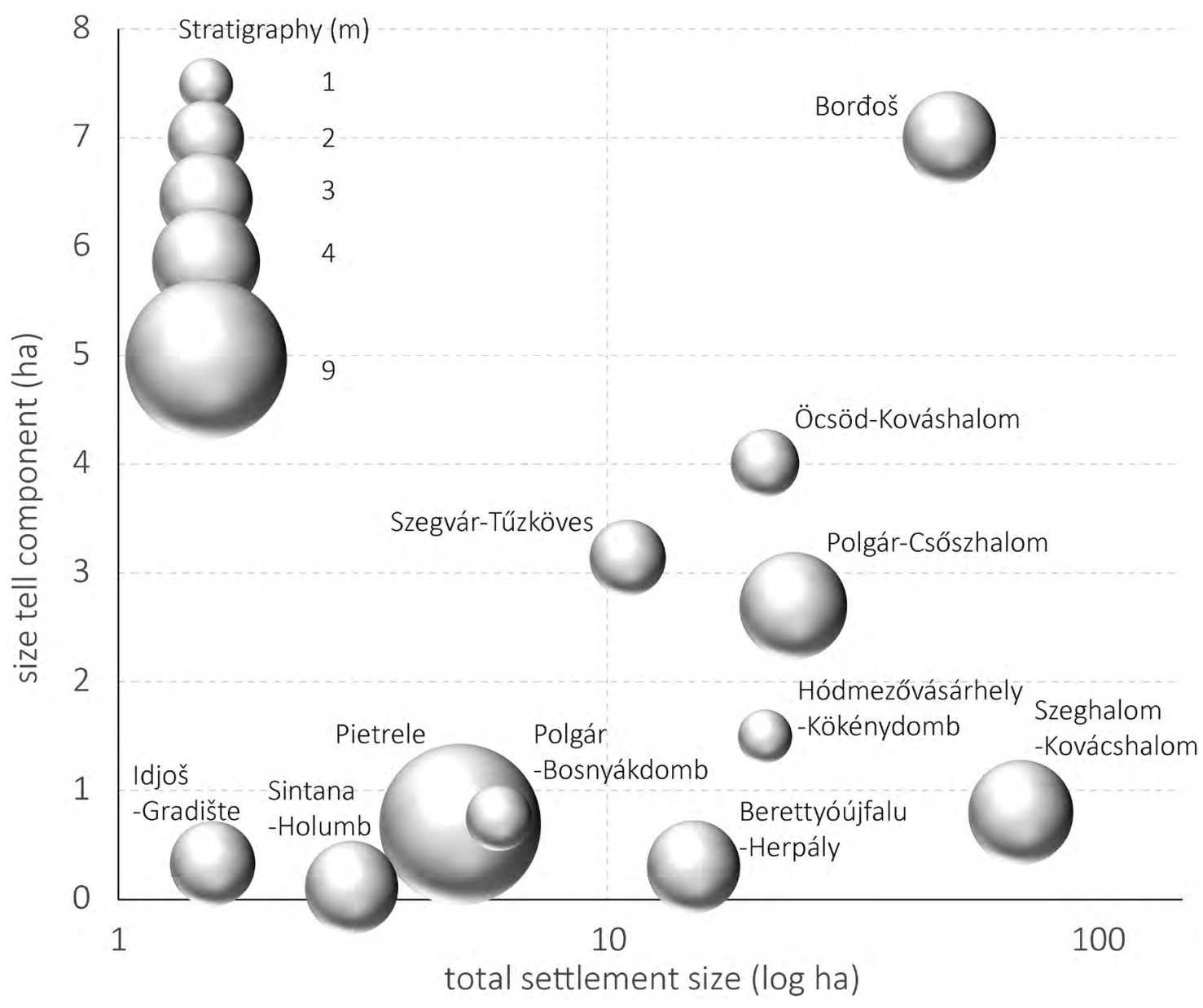

Fig. 5: Selected multicomponent sites of Southeast Europe. Comparative representation of total size, size of the tell component, and the thickness of stratigraphy. The underlying data are listed in table 1 (Source: R. Hofmann).

\section{Borđoš in context: Regional settlement dynamics and local spatial patterns}

Late Neolithic population agglomeration processes in the Tisza region were accompanied by a significant decrease in regional settlement density and number ${ }^{18}$. The result of these agglomeration processes was large flat, tell, or multicomponent sites. At the latest, around 4500 BCE reverse processes led to a sharp increase of the number of settlements and decrease of settlement sizes.

Large multicomponent sites in wide parts of the study area are considered as "focal points", central places, or "supersites" within discrete settlement clusters. These Late Neolithic settlement clusters are supposed to represent groups of sites which were spatially separated from

18 Sherratt 1982; 1983; Kalicz 2001; Parkinson/Gyucha 2012. each other by unsettled areas, including catchment areas in the size range between 14 and $72 \mathrm{~km}^{219}$. This grouping or clustering of sites is interpreted as an indication of some kind of regional "tribal organisation". The term describes segmented and decentralised integrative social units above the societal level of extended family units or bands which might be the result of regular interaction ${ }^{20}$. A settlement structure deviating from the described pattern was found for the Herpály group in the catchment of the Körös River; there, the density of settlement mounds is in general much higher and their size very small ${ }^{21}$.

Borđoš represents one of the southernmost multicomponent sites in the eastern Tisza region, situated at the northern distribution limit of the Vinča cultural complex. Comparable settlement complexes are concentrated in

19 Parkinson 2006, 139-144; Raczky/Füzesi2016.

20 Parkinson 2006, 17-18.

21 Kalicz 1995; Link 2006. 
Tab. 3: Borđoš, Results of Bayesian modelling of ${ }^{14} \mathrm{C}$ dates (for details, including OxCal-codes, consult supplemental material S1).

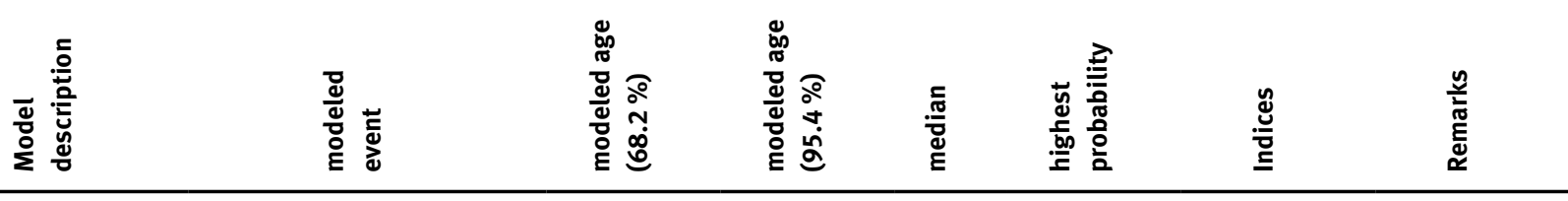

\begin{tabular}{|c|c|c|c|c|c|c|c|}
\hline \multirow{7}{*}{$\begin{array}{l}\text { circular earthwork } \\
\text { (trenches } 2 \text { and } 3 \text { ) } \\
6 \text { dates }\end{array}$} & start ditch backfilling & $5050-4991$ & $5090-4991$ & 5023 & 5025 & \multirow{7}{*}{$\begin{array}{l}A_{\text {model }}=77.5 \\
A_{\text {overall }}=90.6\end{array}$} & \\
\hline & duration backfill 1 & $0-23$ & $0-78$ & 10 & 10 & & \\
\hline & transition backfill 1-2 & $5033-4986$ & $5047-4960$ & 5007 & $5020-5000$ & & \\
\hline & duration backfill 2 & $0-19$ & $0-49$ & 9 & 5 & & \\
\hline & transition backfill 2-3 & $5019-4969$ & $5036-4946$ & 4994 & 5000 & & \\
\hline & duration backfill 3 & $0-27$ & $0-93$ & 12 & 3 & & \\
\hline & end ditch backfilling & $5006-4943$ & $5036-4895$ & 4974 & 4990 & & \\
\hline \multirow{3}{*}{$\begin{array}{l}\text { tell settlement, } \\
\text { upper layer (tren- } \\
\text { ches } 6,7,15,16 \text { ) } \\
6 \text { dates }\end{array}$} & start area 3 & $4812-4696$ & $4923-4621$ & 4758 & 4730 & \multirow{3}{*}{$\begin{array}{l}A_{\text {model }}=80.1 \\
A_{\text {overall }}=76.7\end{array}$} & \multirow{3}{*}{$\begin{array}{l}\text { Poz-90687 } \\
\text { excluded } \\
\text { (poor agree- } \\
\text { ment } 58.8 \% \text { ) }\end{array}$} \\
\hline & duration area 3 & $71-350$ & $0-524$ & 240 & 250 & & \\
\hline & end area 3 & $4619-4451$ & $4683-4341$ & 4525 & 4515 & & \\
\hline \multirow{3}{*}{$\begin{array}{l}\text { tell settlement, } \\
\text { upper layer (tren- } \\
\text { ches } 6,7,15,16 \text { ) } \\
6 \text { dates }\end{array}$} & start area 3 & $4793-4692$ & $4893-4623$ & 4743 & 4743 & \multirow{3}{*}{$\begin{array}{l}A_{\text {model }}=92.7 \\
A_{\text {overall }}=93.9\end{array}$} & \multirow{3}{*}{$\begin{array}{l}\text { Poz-90687 } \\
\text { excluded (poor } \\
\text { agreement) }\end{array}$} \\
\hline & duration area 3 & $0-188$ & $0-399$ & 132 & $0-100$ & & \\
\hline & end area 3 & $4686-4572$ & $4708-4451$ & 4615 & 4620 & & \\
\hline \multirow{7}{*}{$\begin{array}{l}\text { tell settlement, } \\
\text { upper layer } \\
\text { (trenches } 6,7,15 \text {, } \\
\text { 16) } 6 \text { dates }\end{array}$} & start area 3 & $4808-4711$ & $4991-4685$ & 4770 & 4740 & \multirow{7}{*}{$\begin{array}{l}A_{\text {model }}=125.4 \\
A_{\text {overall }}=122.9\end{array}$} & \multirow{7}{*}{$\begin{array}{l}\text { Poz-90687 } \\
\text { excluded } \\
\text { (poor agree- } \\
\text { ment) } \\
\text { Poz-90536 } \\
\text { excluded } \\
\text { (unclear } \\
\text { context) }\end{array}$} \\
\hline & levelling layer under house & $0-68$ & $0-244$ & 37 & 20 & & \\
\hline & $\begin{array}{l}\text { house construction/start } \\
\text { house use }\end{array}$ & $4754-4694$ & $4795-4655$ & 4723 & 4720 & & \\
\hline & duration house use & $0-55$ & $0-122$ & 33 & 30 & & \\
\hline & end house use & $4723-4657$ & $4751-4601$ & 4689 & 4690 & & \\
\hline & duration after house use & $0-74$ & $0-249$ & 39 & 10 & & \\
\hline & end after house use & $4706-4591$ & $4725-4416$ & 4636 & 4680 & & \\
\hline \multirow{5}{*}{$\begin{array}{l}\text { horizontal } \\
\text { settlement } \\
\text { (trenches } 4,5,8,9 \text { ) } \\
5 \text { data }\end{array}$} & start house construction & $4803-4731$ & $4897-4710$ & 4776 & 4770 & \multirow{5}{*}{$\begin{array}{l}A_{\text {model }}=98.4 \\
A_{\text {overall }}=102\end{array}$} & \multirow{5}{*}{$\begin{array}{l}\text { Poz-90477 } \\
\text { excluded } \\
\text { (poor agree- } \\
\text { ment) }\end{array}$} \\
\hline & $\begin{array}{l}\text { duration house construc- } \\
\text { tion }\end{array}$ & $0-47$ & $0-157$ & 24 & $0-50$ & & \\
\hline & $\begin{array}{l}\text { house construction-house } \\
\text { use }\end{array}$ & $4768-4719$ & $4790-4699$ & 4744 & $4770-4720$ & & \\
\hline & duration house use & $0-43$ & $0-140$ & 22 & $0-40$ & & \\
\hline & end house use & $4755-4686$ & $4784-4607$ & 4715 & 4730 & & \\
\hline \multirow{5}{*}{$\begin{array}{l}\text { horizontal } \\
\text { settlement, } \\
\text { (trench 10) } \\
3 \text { dates }\end{array}$} & start house construction & 4934-4802 & $5193-4753$ & 4881 & 4840 & \multirow{5}{*}{$\begin{array}{l}A_{\text {model }}=95.9 \\
A_{\text {overall }}=97.8\end{array}$} & \\
\hline & $\begin{array}{l}\text { duration house construc- } \\
\text { tion }\end{array}$ & $0-84$ & $0-352$ & 42 & 20 & & \\
\hline & $\begin{array}{l}\text { house construction-house } \\
\text { use }\end{array}$ & $4861-4786$ & $4906-4751$ & 4825 & 4820 & & \\
\hline & duration house use & $0-86$ & $0-261$ & 45 & 30 & & \\
\hline & end house use & $4827-4727$ & $4885-4585$ & 4773 & 4790 & & \\
\hline
\end{tabular}


Tab. 3 (continued)

\begin{tabular}{|c|c|c|c|c|c|c|}
\hline \multirow{5}{*}{$\begin{array}{l}\text { horizontal sett- } \\
\text { lement, (trench 11) } \\
2 \text { dates }\end{array}$} & start house construction & 4951-4782 & $5306-4726$ & 4896 & 4840 & \multirow{5}{*}{$\begin{array}{l}A_{\text {model }}=110.2 \\
A_{\text {overall }}=109.1\end{array}$} \\
\hline & $\begin{array}{l}\text { duration house construc- } \\
\text { tion }\end{array}$ & $0-117$ & $0-509$ & 61 & 40 & \\
\hline & $\begin{array}{l}\text { end house construction- } \\
\text { start house use }\end{array}$ & $4840-4751$ & $4895-4720$ & 4799 & 4800 & \\
\hline & duration house use & $0-116$ & $0-474$ & 61 & 50 & \\
\hline & end house use & $4821-4676$ & $4886-4332$ & 4729 & 4730 & \\
\hline \multirow{5}{*}{$\begin{array}{l}\text { horizontal } \\
\text { settlement } \\
\text { (trench 14) ditch } \\
5 \text { dates }\end{array}$} & start ditch fill 1 & $4897-4784$ & $5041-4733$ & 4841 & $4810-4840$ & \multirow{5}{*}{$\begin{array}{l}A_{\text {model }}=104.4 \\
A_{\text {overall }}=108.1\end{array}$} \\
\hline & duration ditch fill 1 & $0-98$ & $0-271$ & 57 & $25-55$ & \\
\hline & transition ditch fill 1-2 & $4808-4794$ & $4836-4722$ & 4781 & 4785 & \\
\hline & duration ditch fill 2 & $0-69$ & $0-186$ & 40 & 55 & \\
\hline & end ditch fill 2 & $4781-4701$ & $4822-4601$ & 4732 & 4730 & \\
\hline \multirow{3}{*}{$\begin{array}{l}\text { horizontal } \\
\text { settlement } \\
\text { (trench 14) vessel } \\
\text { group } \\
3 \text { dates }\end{array}$} & start vessel group & $4807-4692$ & $5051-4619$ & 4750 & 4715 & \multirow{3}{*}{$\begin{array}{l}A_{\text {model }}=119.6 \\
A_{\text {overall }}=116.5\end{array}$} \\
\hline & duration vessel group & $0-186$ & $0-660$ & 106 & 25 & \\
\hline & end vessel group & $4715-4588$ & $4765-4300$ & 4645 & 4690 & \\
\hline
\end{tabular}

the middle and lower course of the Tisza and Körös River, while north of the Körös valley only isolated examples exist (Fig. 1, Tab. 1). These sites show a marked variability regarding size and spatial layout. Only in rare cases do such multicomponent settlements show sizes of more than 20 ha. Regarding both the total size and size of the tell component, Borđoš is at the upper limit of such settlements (Fig. 5).

Modelled ${ }^{14} \mathrm{C}$ dates and relative chronologies from 12 multicomponent sites in the wider study area clearly reveal regionally different trajectories of development (Fig. 6, Tab. 1, S1-2). Paralleling the gradual northward spread of the specific mound-forming settlement behaviour, the start of the formation of the tell components was staggered. While in the southern part of the Tisza region the accumulation of settlement mounds began around 5200 BCE, the onset of mounds in the Körös River Basin occurred slightly later around $5000 \mathrm{BCE}^{22}$. In the distribution area of the Herpály group in the middle course of the Körös River, tell formation started not before 4850 BCE and with highest probability dated in the $46^{\text {th }}, 45^{\text {th }}$ and $44^{\text {th }}$ centuries BCE. The same is true for the area north of the catchment of the Körös River, where settlement mounds represent a general exception exclusively related to large central sites of the Csőszhalom Group. After 4700 BCE the

22 Raczky 2015.
${ }^{14} \mathrm{C}$ datings in the southern part of the study area decrease while they increase in the northern part. In all regions, tells were abandoned at the latest by 4450 BCE.

Although far fewer ${ }^{14} \mathrm{C}$ dates are available from the flat settlement components of these complex sites, the onset of this phenomenon appears to have been much more uniform across the study region. The flat settlements from Borđoš and Polgár-Csőszhalom both date to the time between 4850 and 4700 BCE. Also, according to their relative-chronological synchronisation with "classical Tisza" ${ }^{23}$ and Vinča $\mathrm{C} 2 / \mathrm{C}-\mathrm{D}^{24}$, the flat-components in the settlements Idjoš, Szeghalom-Kovácshalom, and Öcsöd-Kováshalom most likely date to the same period. The settlement of Berettyóújfalu-Herpály seems to represent an exception, since here the flat component was occupied earlier and related to Early Tisza/Late Szakálhát.

According to the collected data, the period between 4850 and 4700 BCE marks the climax of the Late Neolithic population agglomeration within large multicomponent settlements of the Tisza region. In the southern parts of the study area, we observe the enlargement of already existing tell settlements by large flat settlements, while at the same time in the upper courses of the Tisza and Körös Rivers the formation of new flat sites took place. In con-

23 Chronology after Horváth 2005.

24 Chronology after Tasić et al. 2016. 


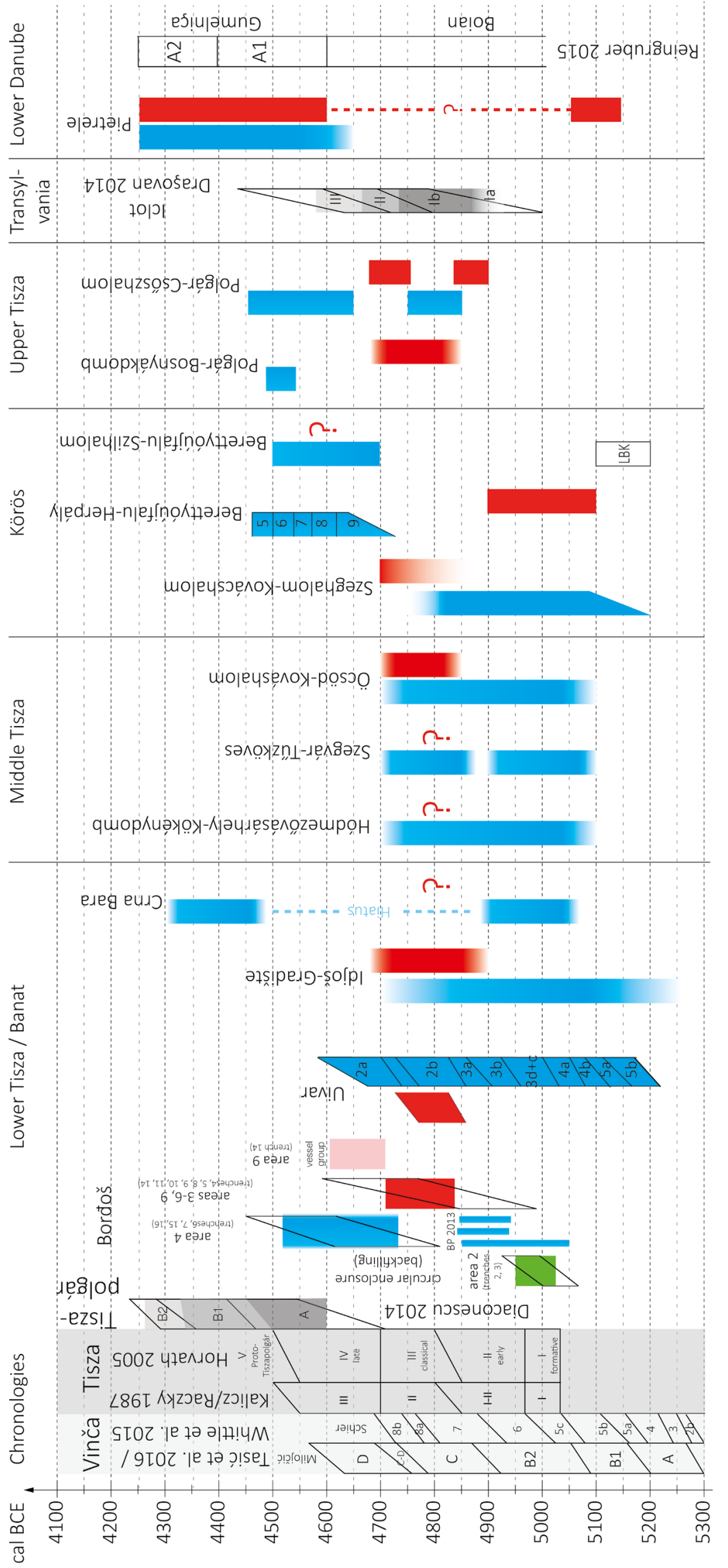


trast to the south, in the north tells should not be understood as the original nuclei of large settlements, but rather as longer occupied possibly separated areas within such flat sites which might have had special functions leading to the different spatial behaviours. Indicators for possible special functions of tell components were found in settlements of the Csőszhalom-group like Polgár-Csőszhalom and Hajdúböszörmény-Pródi-halom. In those sites the tell components developed within rondel-type circular enclosures which emerge slightly later also in Lengyel contexts in the western part of the Carpathian Basin. In contrast to many Transdanubian cases, within the interior space of the earthwork from Polgár-Csőszhalom intensive settlement activity took place, possibly associated with a building with special functions ${ }^{25}$.

Concerning the subsistence strategies in these sites, data on animal exploitation and plant cultivation indicate an intensive mixed farming economy, within which horticulture and animal husbandry potentially represent interdependent components due to the demand for animal excrement for manuring ${ }^{26}$. Isotope data show a distinct and surprising lack of mobility of humans and animals which is interpreted as an indicator for an intensive garden economy with a high demand on man power ${ }^{27}$. So far, in contrast to settlements in the central and western Balkan low-middle mountain ranges ${ }^{28}$, there are also no clear indicators for seasonal forms of transhumance in the adjacent uplands.

From around 4700 BCE on a surprisingly consistent reversal trend towards de-nucleation and the development of more dispersed settlement patterns began. This is the case not only the Tisza Region ${ }^{29}$, but also in the much larger areas of the Western and Central Balkans ${ }^{30}$. Around 4700 BCE not only many flat site components in the Tisza and Körös River Basin were abandoned, but also many tell sites in the distribution areas of societies with Vinča and Butmir pottery styles.

Multicomponent sites show a wide range of settlement layouts which might indicate different degrees of communal integration. In cases like Polgár-Csőszhalom, Szeghalom-Kovácshalom, or Uivar tells are situated in the centres of more or less extensive flat settlements which seems to indicate direct mutual relations and perhaps also special functions of the tell components. In other cases, like

25 Raczky/Sebők 2014.

26 Hoekman-Sites/Giblin 2012.

27 Giblin et al. 2013; Hoekman-Sites/Giblin 2012; Gamarra et al. 2018.

28 Müller-Scheeßel et al. 2010b; Hoekman-Sites/Giblin 2012.

29 Link 2006; Raczky 2015; Bánffy et al. 2016.

30 Borić 2015; Whittle et al. 2016; Hofmann 2015.
Borđoš, the settlement mounds and the flat settlements form discrete units.

Concerning the social relations between the different settlement components, there are different patterns. When the settlement layouts are uniform between different components in sites like Borđoš, this may be interpreted as showing higher degrees of communal integration. In contrast, for sites like Szeghalom-Kovácshalom, where houses in the flat settlement are grouped in potentially more independent small clusters or neighbourhoods, less community-wide integration and higher independence of neighbourhoods seems likely. A more dispersed distribution of settlement activities has also been proven in the settlement Öcsöd-Kováshalom, where around the central tell-like locus 7 several horizontal habitation clusters developed.

A new aspect of settlements which must be considered for the Banat and Vojvodina - and is exhibited, for the first time, at Borđoš - is what can be called the centripetal spatial layout: houses arranged around the centre of the settlement forming a central open space on both settlement mounds and in the flat settlements (Fig. 7). So far, such a centripetal settlement layout in the wider working area is exclusively known from Iclod, Transylvania and from settlements of the Cucuteni-Tripolye complex east of the Carpathians ${ }^{31}$. In the Cucuteni-Tripolye cultural complex, variants of such settlement layouts represent the predominant principle of settlement organisation, starting at the latest in the last centuries of the $5^{\text {th }}$ millennium $\mathrm{BCE}^{32}$. In contrast, in the central and western Balkan region, and also in the Tisza region, a settlement organisation with uniformly oriented, free-standing houses is the most common (Fig. 8). However, both organisational principles show major variability regarding the degree of row-formation, building density, arrangement and grouping of houses, and location of central squares. This variability is likely due to differences in household composition (e. g. nuclear family vs. multi-family households) ${ }^{33}$.

\section{Discussion}

Considering the temporal dynamics of multicomponent sites and their different properties, as laid out above, combinations of tells and flat settlements in the Tisza region are likely in the most cases the result of an overall trend

31 Shishkin 1985; Rassmann et al. 2014.

32 Hofmann et al. 2016.

33 Tripković 2009. 


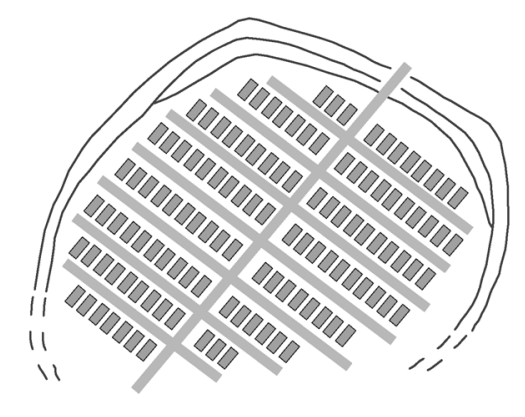

a
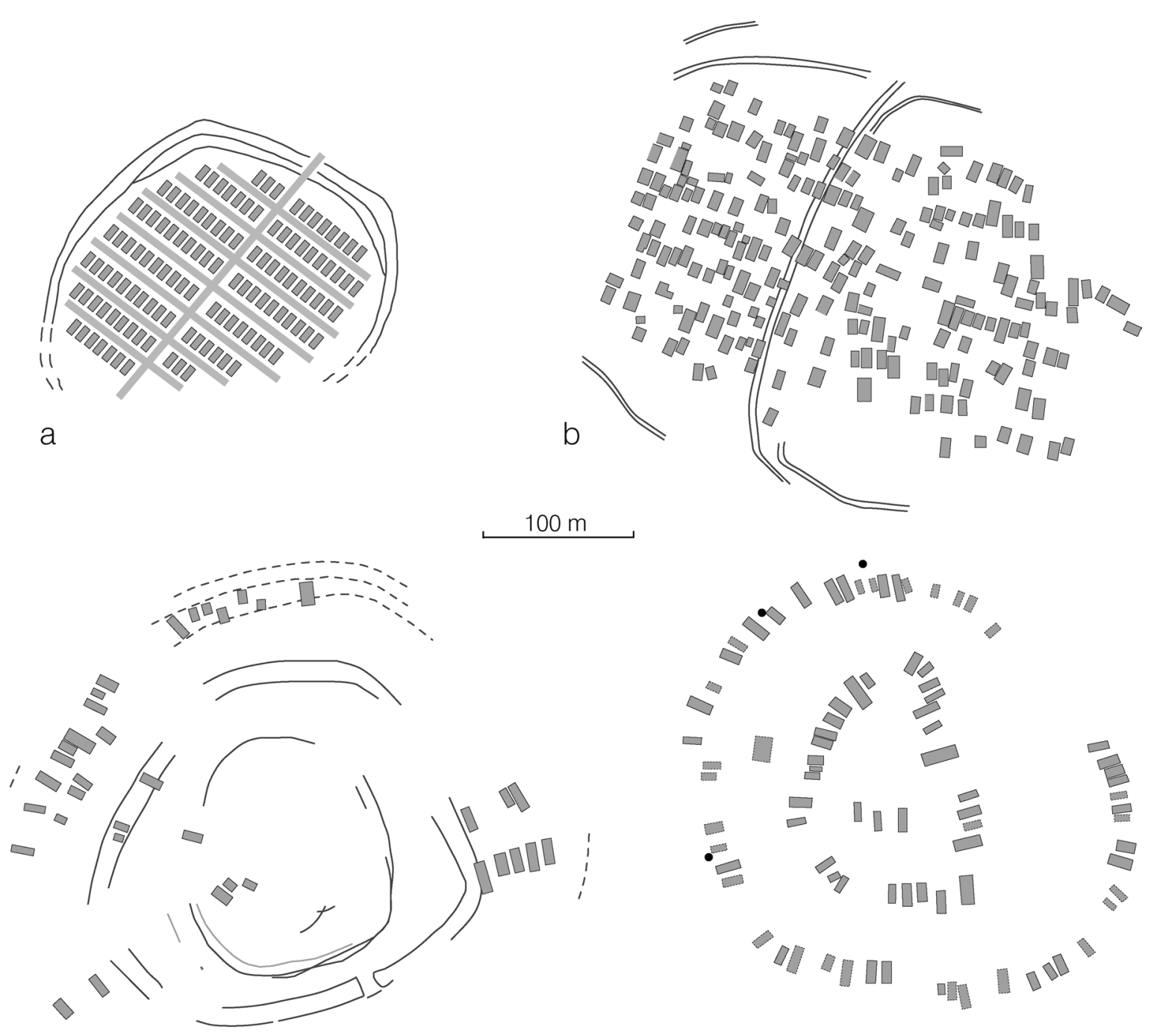

C

Fig. 7: Examples of different principles of settlement organisation from Southeast and East Europe: a) Okolište (after Müller-Scheeßel et al. 2010a) - "true row pattern" with houses arranged in dense rows; b) "false row pattern" with equally directed houses which are, however, not so clearly arranged in rows and might in many cases not be contemporary; c) Iclod (after Mischka 2012) - centripetal pattern with central public square; d) Moshuriv (after Ohlrau 2019) - centripetal pattern with circumferential main road.

of continued agglomeration processes which show different regional trajectories. At the middle and lower course of the Tisza River, like in the case of Borđoš, pre-existing tell settlements constituted the starting point of settlements which later were greatly enlarged. Contrastingly, in the Körös and Upper Tisza region, tells represent distinct areas within the larger flat settlements which developed into spatially more fixed tell structures. Thus, they are the result of the reduction of the settlements in size or - as probably in the case of Polgár Csőszhalom - related to special functions ${ }^{34}$.

34 Raczky/Sebők 2014.
The development of large multicomponent settlements reflects the general trend in Southeast Europe towards population agglomeration which started between $5300 / 5200$ and 4800 BCE in a regionally differentiated manner and reached its climax between 4850 and 4700 BCE. The trend is likely the result of population growth and inter-site mobility. A reversal of this trend after $4700 \mathrm{BCE}$ is clearly visible and led, until $4450 \mathrm{BCE}$, to the gradual reorganization of settlement patterns towards much smaller, more dispersedly distributed communities. Frequently, large flat settlements were given up in the course of this process while many tells "survived" the following 200 years, or rather only then emerged in settlements clearly reduced in size. 


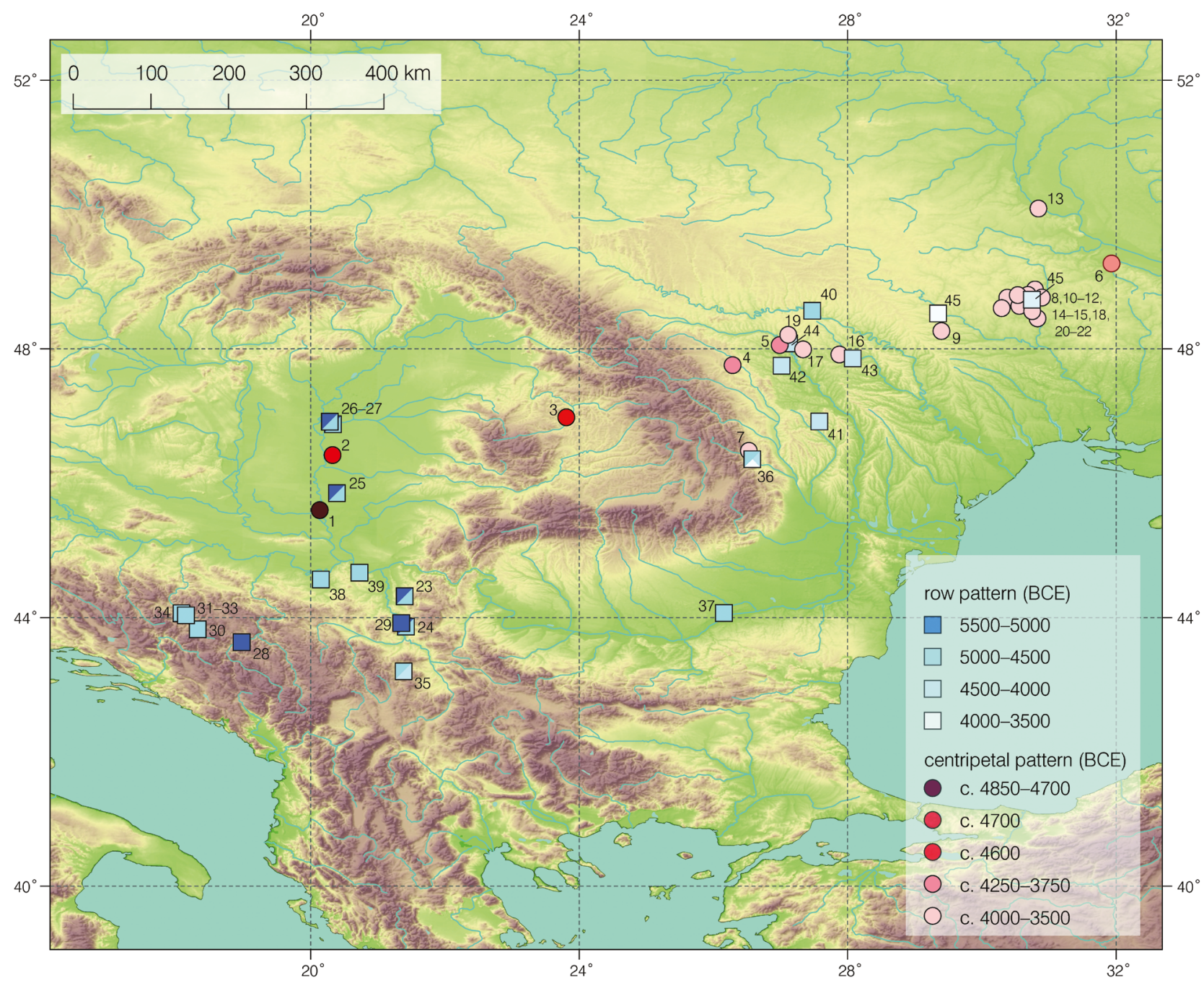

Fig. 8: Map of settlement layouts with row pattern and centripetal pattern in a transect between the western Balkan peninsula and the Dnieper. Base map: SRTM 1 Arc-Second Global. Geodetic system: WGS84 latitude longitude. Centripetal pattern: 1 Borđoš; 2 Hódmezővásárhely-Gorzsa; 3 Iclod B; 4 Adâncata-Dealul Lipovanului zone B; 5 Brinzeni 8; 6 Grebeni; 7 Poduri-Dealul Ghindaru; 8 Apolianka; 9 Bilyi Kamin; 10 Dobrovody; 11 Fedorivka / Mykhailivka; 12 Glybochok, Hlybochok; 13 Kolomijschina 1; 14 Maidanetske; 15 Nebelivka; 16 Petreni; 17 Stolniceni I; 18 Talianki; 19 Trinca-Izvorul lui Luca; 20 Volodymyrovka; 21 Yampil; 22 Yatranivka I. Row pattern: 23 Belovode; 24 Drenovac, Slatina - Turska Česma; 25 Idjoš-Gradište I; 26 Öcsöd-Kováshalom A; 27, Őcsőd-Kováshalom B; 28 Jagnilo; 29 Paraćin-Motel Slatina; 30 Butmir; 31-33 Okolište; 34 Kundruci; 35 Pločnik; 36 Poduri-Dealul Ghindaru; 37 Pietrele I-Magura Gorgana; 38 Stubline-Crkvine; 39 Vinča-Belo Brdo; 40 Bernashevka; 41 Scânteia-Dealul Bodeştilor; 42 Truşesti; 43 Putineşti III; 44 Brinzeni-0striv; 45 Trostianchyk; 45 Grebenyukuv Yar (Source R. Hofmann).

Comparing the central and western Balkan uplands ${ }^{35}$ and the Tisza region ${ }^{36}$, a widely synchronous development of settlement agglomeration took place albeit in different ways (larger tell settlements as opposed to multicomponent sites). An important difference is that the settlement behaviour which led to the emergence of tells was a longerlived tendency in the Tisza region. In the Tisza region post-agglomeration development took the character of a

35 Link 2006; Borić 2015; Hofmann 2015.

36 Raczky 2015; Bánffy et al. 2016. gradual reorganization, while that in the Central Balkans seems to a much greater extent to be associated with depopulation. In the former region the "cultural concept" of long-lasting settlement permanence and the social configuration behind it eventually loses its importance. Instead, intra-mural and later extra-mural cemeteries evolved into spatial anchors and focal points of societies ${ }^{37}$.

In spite of the locally focused requirements of the subsistence economy (see above), in Borđoš and other large

37 Link 2006. 
settlements clear indications for complex regional interaction and exchange in different directions are abundant. In consideration of its specific characteristics, complex multi-level regional networks and interactions, including inter-group mobility and admixture, are much more likely than the traditional culture-historical premise of culturally homogeneous peoples. In Borđoš, for example, the regular use of both Vinča and Tisza style pottery vessels in the same houses clearly points to the existence of overlapping, or simultaneously active, social relations with different regions, namely the Balkans and the Carpathian Basin. In addition, as referred to above, a differential occurrence of flint raw materials between tell and flat settlement also points to the existence of different regional networks intersecting on the site. This seems to be in accordance with different attitudes of flint use connected with the two spatial spheres of the Polgár settlement complex ${ }^{38}$.

Further references to external social relations can be seen in elements of the settlement plan. For example, the occurrence of the circular enclosure with a double ditch spatially separated from the settlement during the earliest phase of the settlement has its best parallels in other regions of the Carpathian Basin ${ }^{39}$. The enclosure represents one of the earliest known cases in which the endings of the double ditch are radially connected with each other. This type of gate occurs in Iclod and also in numerous circular Lengyel enclosures of the $48^{\text {th }}$ and $47^{\text {th }}$ century BCE ${ }^{40}$.

Other aspects of the settlement plan from Borđoš cannot be connected to any specific region so far. Widely known, but not concentrated in regions are, for example, v-shaped ditches which are regularly used in both Lengyel enclosures and certain Vinča settlements ${ }^{41}$. The circular layout of Borđoš has earlier analogies in Uivar in the Banat ${ }^{42}$, but also in the probably slightly younger Lengyel settlement Sormás Török-földek in Transdanubia ${ }^{43}$ or in Iclod in Transylvania ${ }^{44}$. In Sormás Török-földek we also find numerous gates, which, however, do not show inwardly directed ditch endings. Analogies for such gates are actually only found in Lengyel circular enclosures, where they seem to be slightly younger ${ }^{45}$. In contrast to the centripetal arrangement in Borđoš, houses in Lengyel settlements usually show uniform north-south orientation.

38 Faragó 2017.

39 Raczky/Anders 2012.

40 Mischka 2012; Literski/Nebelsick 2012.

41 Borić et al. 2018.

42 Schier 2014; Draşeovan et al. 2017.

43 Barna/Pásztor 2011; Barna 2017.

44 Mischka 2012; Lazarovici 2013.

45 Literski/Nebelsick 2012.
In the settlement of Iclod in Transylvania we observe a spatial configuration similar to Borđoš, with houses also directed towards the centre of the settlement ${ }^{46}$. Also in Dimini in Thessaly, Greece, concentric rings of houses are grouped around the settlement centre which is accessible through radial alleys ${ }^{47}$. However, in both cases the exact dating and the internal chronology of these layouts remain unclear: Dimini is dated between 4800 and $4500 \mathrm{BCE}^{48}$. In the case of Iclod only the innermost ditch is dated to early stages of the Iclod group ${ }^{49}$, while the centripetal arrangement of houses visible in the magnetic plan most likely represents a later stage of the settlement. According to radiometric data from associated cemeteries, this later phase should be dated rather around or after 4700 BCE than before ${ }^{50}$.

Overall, the multiple external relations materialized in both settlement configuration and material culture at Borđoš should be highlighted. Corresponding hybrid fusions of differently regionally located aspects as in Borđoš are also observable in the Upper Tisza region, where in Polgár-Csőszhalom and Polgár-Bosnyákdomb linear arrangements of houses in the flat settlement are combined with circular ditch systems of Lengyel style ${ }^{51}$.

Late Neolithic settlement and burial data, so far, do not reveal signs for a pronounced vertical social hierarchy or social inequality in Late Neolithic settlements of the Tisza region ${ }^{52}$. It has been argued ${ }^{53}$, and there is no empirical evidence to the contrary, that Neolithic societies were organised in a comparably egalitarian manner with an ideology oriented towards communality, applying strategies to prevent the emergence of social inequality. Yet, the emergence of autonomous households, the necessity to store foodstuffs, and differential economic productivities within the community might have created a constant tension between values of communality and sharing, and an emerging potential for economic inequality ${ }^{54}$, intra-group competition, and differential levels of political power. These tensions might have been intensified in the context of growing settlement community sizes and thus might have constituted an important factor in the de-nu-

46 Mischka 2012; Lazarovici 2013.

47 Souvatzi 2008, 107-160; Furholt 2017.

48 Souvatzi 2008, 108.

49 Lazarovici 1991.

50 Diaconescu 2015.

51 Raczky/Anders 2010; 2016.

52 Siklósi 2013.

53 Sahlins 1974; Porčić 2012.

54 Halstead 2006, Leppard 2014. 
cleation processes which led to more dispersed settlement patterns at the transition to the Early Copper Age ${ }^{55}$.

We argue that within the social melting-pot of the multicomponent settlements, different social strategies to mitigate the potential social tensions were pursued. We contend that some of these are visible in the overall settlement layout of house placement. A frequent pattern is that of the "Early Balkan village" with the basic pattern of free-standing houses in more or less regular rows ${ }^{56}$. This pattern emphasises the autonomy and the equality of the individual houses to a stronger degree than in agglutinated clustered neighbourhoods of early Middle Eastern settlements. At the same time, the element of regular house placement reconciles this autonomy with the overall village communality. However, referring to the example of the Late Neolithic site Okolište, it was argued that settlements with such linear arrangements of houses are marked by high degrees of axiality and that they largely lack any convex space which would highlight the importance of the negotiation of communal concerns ${ }^{57}$. This layout allows for a pronounced social monitoring and thus most likely strengthens top-down communal interests at the cost of individuals or households.

In contrast, a centripetal pattern, while still highlighting house equality, most visibly emphasises the central convex space. The main difference to the house-row layout therefore points to a more important role of social negotiations; that is, communality built upon bottom-up agency. Lee (2007) has argued that in the context of non-ranked segmentary societies with growing community size, centripetal plans are considered to facilitate the maintenance of social equality via consensus-based decision making ${ }^{58}$.

Thus, the two patterns of settlement organization resolve the tension between house autonomy and settlement wide communality in different ways. While both highlight household autonomy and equality through equal sizes and shapes of houses and their spatial isolation (being free-standing), they still indicate different modes through which village communality is expressed. In a centripetal arrangement, house autonomy and equality is secondary to one further factor, the centre, which represents, in this period, the communal space. In this way, communal gatherings are literally taking place at the heart of village space; they predetermine the position and relation of all other social units of the village community. The axial settlement represents a similar, still significantly

55 Müller et al. 2013a; Gyucha 2015, Arponen et al. 2015; Borić 2015. 56 Furholt 2017; derived from Chapman 1989.

57 Müller-Scheeßel et al. 2010a; Müller et al. 2011; 2013a. 58 Lee 2007. different social order, one where autonomy and equality are paired with a social conformity that seems more fixed, lacking the bottom-up aspect of a communal gathering. To conclude, we interpret the axial variant of settlement layout as a more authoritarian way of keeping an egalitarian way of life.

Thus, in our view, under the overall condition of constant conflict between household-based resource extraction, storage, and accumulation that could potentially lead to competitive behaviour, as well as of village-wide communality and solidarity, the axial and the centripetal settlement patterns represent two social strategies of reconciliation expressing both equality and individuality, yet with different focuses on the importance of communality. To use a modern analogy, one could refer to the difference between Communism (axial arrangement) and Anarchism (centripetal arrangement).

The centripetal layout is an expression of a mode of social organisation which values communal decision-making to a higher degree than it is in an axial layout. Overall, we interpret the plan of Borđoš as revealing a high degree of communal integration which might be supported in the flat settlement of Borđoš by the frequent renewal of the enclosure system - on average every 20 years (i. e. every generation). In practice, the central open space was necessary and used to negotiate the communal concerns.

Both principles of settlement organisation represent different attempts of societies to maintain societal balance and social equality. The differences could be, for example, due to the fact that local resources such as arable land tend to be scarce in the low-middle mountain ranges of the Central and Western Balkans ${ }^{59}$. This shortage of resources potentially raised the chances of the emergence of social inequality ${ }^{60}$ and, equally, could have allowed the realisation of more authoritarian social rules to prevent the potential of this inequality evolving. In contrast, in the Tisza region, arable land was available in sufficient quantity. Thus, every inhabitant would have had the opportunity to leave and take up farming somewhere else, something discussed in the modern era as "voting with your feet". The formation of the centripetal settlement layout which is focused on communal negotiations could indicate that manpower for intensive gardening and related animal husbandry was more valued as a critical resource. Regardless, the possibly more "democratic" social organisation which is indicated by a new type of settlement organisation in the southern part of the Tisza region might have been a factor which contributed to a more gradual transition to

59 e. g. Müller 2006.

60 cf. Hofmann et al. 2010; Müller et al. 2011; Arponen et al. 2015. 
the Early Copper Age than was the case in the Central and Western Balkan region where the end of the age of tells rather had the character of a collapse.

So far, the flat settlement in Borđoš, which was founded around 4850 BCE, represents one of the earliest examples of a centripetal settlement layout with a central square in Neolithic Southeast Europe. Similar principles of settlement organisation were applied from around 4700 BCE or later in Iclod $^{61}$ and Gorzsa $C^{62}$. Preliminarily, it remains an open question if this "clustering" of early examples might indicate the origin of this settlement form in the Tisza region.

\section{Conclusion}

The centripetal settlement layout which was established in Borđoš at the latest by 4850 BCE was something new in the region, which can be explained partly from contacts to Transylvania (Iclod), Transdanubia (Lengyel), and perhaps also modern day Greece (Dimini). The break with the already long-established linear settlement layout and the emergence of multicomponent settlements most likely represent the outcome of a transregional trend towards accelerated population agglomeration in fewer sites and a negotiation-based socio-political organization. Our absolute-chronological analyses show that this phase of temporarily accelerated population agglomeration was roughly limited to the time between 4900 and 4700 BCE. As part of this agglomeration process, people of different origin and involved in differently directed regional networks joined together in large settlements. The detailed reasons for this development remain unclear. As the overall heterogeneous and sometimes hybrid character of these multicomponent settlements and their material culture impressively show, these population agglomerations represented an innovative environment in which new forms of political organization and social coexistence appear to have emerged.

Acknowledgements: The research at Borđoš was possible through Postdoc funding from the Graduate School "Human Development in Landscapes", by financial support from the German Research Foundation (Research Grant Ho 5176/1 "Interaction in the central and western Balkan during the Neolithic and Early Eneolithic), and by funds from the State of Serbia. We are very grateful to

61 Mischka 2012. 62 Horváth 1990. the municipality Novi Bečej who supported our project actively in numerous respects. We are most grateful to Joca Bakalov, Zrenjanin, who opened his enormous local and archaeological knowledge for the service of our research. Furthermore, we are grateful to Cheryl A. Makarewicz, Rebekka Eckelmann, and Sarah Pleuger, all Kiel, who determined the species represented by the bones for ${ }^{14} \mathrm{C}$-dating. Due to thematic interlinking, this paper was written in the frame of the sub-project D1 "Population agglomerations at Tripolye-Cucuteni mega-sites" of the collaborative research centre CRC1266 "Scales of Transformation - Human-Environmental Interaction in Prehistoric and Archaic Societies" (German Research Foundation - Project number 2901391021 - SFB 1266). We would like to thank Alasdair Whittle, Pál Raczky and anonymous reviewers for valuable criticism and advice that have contributed significantly to the improvement of the paper. We are last but not least very grateful to Vesna Medović for the translation of the abstract into French.

\section{Bibliography}

Arponen et al. 2015: V. P. J. Arponen/J. Müller/R. Hofmann/ M. Furholt/A. Ribeiro/C. Horn/M. Hinz, Using the Capability Approach to Conceptualise Inequality in Archaeology: the Case of the Late Neolithic Bosnian Site Okolište c. 5200-4600 bce. Journal of Archaeological Method and Theory 2015, 1-20.

Bandy 2004: M. S. Bandy, Fissioning, Scalar Stress, and Social Evolution in Early Village Societies. American Anthropologist 106, 2, 2004, 322-333.

Bánffy et al. 2013 (2016): E. Bánffy/A. Osztás/K. Oross/I. ZalaiGaàl/T. Marton/É. Á. Nyerges, The Alsónyék story: towards the history of a persistent place. Bericht der Römisch Germanischen Kommssion 94, 2013 (2016), 283-318.

Barna 2017: J. P. Barna, The Formation of the Lengyel Culture in South-Western Transdanubia (Budapest 2017).

Barna/Pásztor 2011: J. P. Barna/E. Pásztor, Different ways of using space: traces of domestic and ritual activities at a Late Neolithic settlement at Sormás-Török-földek. Documenta Praehistorica 38, 2011, 1-22.

Bocquet-Appel/Bar-Yosef 2008: J.-P. Bocquet-Appel/O. Bar-Yosef (Eds.), The Neolithic Demographic Transition and its Consequences (Berlin/Heidelberg 2008).

Bogaard 2005: A. Bogaard, 'Garden Agriculture' and the Nature of Early Farming in Europe and the near East. World Archaeology 37, 2, 2005, 177-196.

Borić 2015: D. Borić, The end of the Vinca world: Modelling the Neolithic to Copper Age transition and the notion of archaeological culture. In: Hansen et al. 2015, 157-217.

- et al. 2018: -/B. Hanks/D. Šljivar/M. Kočić/J. Bulatović/ S. Griffiths/Roger Doonan/D. Jacanović, Enclosing the Neolithic World: A Vinča Culture Enclosed and Fortified Settlement in the Balkans. Current Anthropology 59, 3, 2018, 336-346. 
Bronk Ramsey 2009: C. Bronk Ramsey, Bayesian analysis of radiocarbon dates. Radiocarbon 51, 2009, 337-360.

- 2017: -, Methods for Summarizing Radiocaron Datasets. Radiocarbon 59, 2, 2017, 1809-1833.

Chapman 1989: J. C. Chapman, The early Balkan village. In: S. Bökönyi (Ed.), Neolithic of Southeastern Europe and its Near Eastern Connections. Varia Archaeologica Hungarica 2 (Budapest 1989) 33-53.

- 1990: -, Social inequality on Bulgarian Tells and the Varna Problem. In: R. Samson (Ed.), The social archaeology of houses (Edinburgh 1990) 49-98.

- 2007: -, The origins of tells in Eastern Hungary. In: P. Topping (Ed.), Neolithic landscapes. Neolithic Studies Group Seminar Papers 2 (Oxford 2007) 139-187.

- 2008: -, Meet the ancestors: settlement histories in the Neolithic In: D. W. Bailey/A. Whittle/D. Hofmann (Eds.), Living well together? Settlement and materiality in the Neolithic of South-East and Central Europe (Oxford 2008) 68-80.

Diaconescu 2015: D. Diaconescu, Considerations Regarding the Absolute Chronological Position of the Prehistoric Cemeteries from Iclod. In: C. Virag (Ed.), Neolithic Cultural Phenomena in the Upper Tisza Basin. International Conference, July 10-12, 2014, Satu Mare (Satu Mare 2015) 248-265.

Draşovean et al. 2017: F. Draşovean/W. Schier/A. Bayliss/ B. Gaydarska/A. Whittle, The Lives of Houses: Duration, Context, and History at Neolithic Uivar, Romania. European Journal of Archaeology 20, 4, 2017, 636-662.

Duffy u. a. 2013: P. R. Duffy/W. A. Parkinson/A. Gyucha/R. W. Yerkes, Coming Together, Falling Apart: A Multiscalar Approach to Prehistoric Aggregation and Interaction on the Great Hungarian Plain. In: J. Birch (Ed.), From Prehistoric Villages to Cities Settlement Aggregation and Community Transformation (New York and London 2013) 44-62.

Dunbar 1992: R. I. M. Dunbar, Neocortex size as a constraint on group size in primates. Journal of Human Evolution 22, 6, 1992, 469-493.

Faragó 2017: N. Faragó, Differences in the selection of raw materials at the site of Polgár-Csőszhalom, northeast Hungary. Bulgarian e-Journal of Archaeology 7, 2017, 85-115.

Forţiu/Cîntar 2014: S. Forţiu/A. Cîntar (eds.) ArheoVest Il1. In Honorem Gheorghe Lazarovici, Interdisciplinaritate în Arheologie (Szeged 2014).

Furholt 2017: M. Furholt, Das ägäische Neolithikum und Chalkolithikum: Transformationen sozialer Handlungsmuster in Anatolien und Griechenland zwischen 6500 und 4000 v. Chr. Universitätsforschungen zur prähistorischen Archäologie 304. Neolithikum und Chalkolithikum in Südosteuropa 3 (Bonn 2017).

- et al. 2014: -/J. Bátora/I. Cheben/H. Kroll/P. Tóth, Vráble-Velké Lehemby: Eine Siedlungsgruppe der Linearkeramik in der Südwestslowakei. Vorbericht über die Untersuchungen der Jahre 2010 und 2012 und Deutungsansätze. Slovenská Archeológia 62/2, 2014, 227-266.

Gamarra et al. 2018: B. Gamarra/R. Howcroft/A. McCall/J. Dani/ Z. Hajdú/E. G. Nagy/L. D. Szabó/L. Domboróczki/l. Pap/ P. Raczky/A. Marcsik/Z. K. Zoffmann/T. Hajdu/R. N. M. Feeney/ R. Pinhasi, 5000 years of dietary variations of prehistoric farmers in the Great Hungarian Plain. PLOS ONE 13/5, 2018, e0197214, https://doi.org/10.1371/journal.pone.0197214.
Giblin et al. 2013: J. I. Giblin/K. J. Knudson/Z. Bereczki/G. Pálfi/ I. Pap, Strontium isotope analysis and human mobility during the Neolithic and Copper Age: a case study from the Great Hungarian Plain. Journal of Archaeological Science 40/1, 2013 , 227-239.

Gyucha 2015: A. Gyucha, Prehistoric Village Social Dynamics.The Early Copper Age in the Körös Region (Budapest 2015).

- et al. 2015: -/R. W. Yerkes/W. A. Parkinson/A. Sarris/N. Papadopoulos/P. R. Duffy/R. B. Salisbury, Settlement Nucleation in the Neolithic: A Preliminary Report of the Körös Regional Archaeological Project's Investigations at Szeghalom-Kovácshalom and Vésztő-Mágor. In: S. Hansen et al. 2015, 129-142.

Halstead 2006: P. Halstead, Sheep in the Garden: The Integration of Crop and Livestock Husbandry in Early Farming Regimes of Greece and Southern Europe. In: D. Serjeantson/D. Field (Eds.), Animals in the Neolithic of Britain and Europe. Neolithic Studies Group Seminar Papers 7 (Oxford 2006) 42-55.

Hansen et al. 2015: S. Hansen/P. Raczky/A. Anders/A. Reingruber (eds.), Neolithic and Copper Age between the Carpathians and the Aegean Sea. Chronologies and Technologies from the $6^{\text {th }}$ to the $4^{\text {th }}$ Millennium BCE. International Workshop Budapest 2012 (Bonn 2015).

- et al. 2012: -/M. Toderaş/A. Reingruber/J. Wunderlich/N. Benecke/I. Gatsov/E. Marinova/M. Müller/C. Nachev/P. Nedelcheva/D. Nowacki/A. Röpke/J. Wahl/S. Zäuner, Pietrele an der Unteren Donau. Bericht über die Ausgrabungen und geomorphologischen Untersuchungen im Sommer 2011. Eurasia Antiqua 18, 2012, 1-68.

- et al. 2014 (2017): -/M. Toderaş/J. Wunderlich/K. Beutler/ N. Benecke/A. Dittus/M. Karaucak/M. Müller/D. Nowacki/ A. Pint/T. D. Price/K. Ritchie/D. Steiniger/T. Vachta, Pietrele am „Lacul Gorgana“. Bericht über die Ausgrabungen in der neolithischen und kupferzeitlichen Siedlung und die geomorphologischen Untersuchungen in den Sommern 2012-2016. Eurasia Antiqua 20, 2014 (2017), 1-116.

Hodder 2014: I. Hodder, Çatalhöyük: the leopard changes its spots. A summary of recent work. Anatolian Studies 64, 2014, 1-22.

Hoekman-Sites/Giblin 2012: H. Hoekman-Sites/J. I. Giblin, Prehistoric animal use on the Great Hungarian Plian: A synthesis of isotope and residue analysis from the Neolithic and Copper Age. Journal of Anthropological Archaeology 31, 2012, 515-527.

Hofmann 2015: R. Hofmann, The Bosnian Evidence: The New Late Neolithic and Early Copper-Age Chronology and Changing Settlement Patterns. In: Hansen et al. 2015, 219-241.

- et al. 2016: -/S. Terna/C.-E. Ursu/L. Brandtstätter/H. Tiede/ W. Mainusch/S. Authenrieth, Spatial organization and population size of small Cucuteni-Tripolye settlements: Results of geomagnetic surveys in Baia and Adâncata, Suceava County, Bucovina, Eastern Romania. Journal of Neolithic Archaeology 18, 2016, 157-189

- et al. 2006: --/Z. Kujundžić-Vejzagić/J. Müller/N. MüllerScheeßel/K. Rassmann, Prospektionen und Ausgrabungen in Okolište (Bosnien-Herzegowina): Siedlungsarchäologische Studien zum zentralbosnischen Spätneolithikum (5300-4500 v. Chr.). Bericht der Römisch-Germanischen Kommission 87, 2006, 1-140.

- et al. 2012: -/F.-K. Moetz/J. Müller (Eds.), Tells: Social and Environmental Space. Proceedings of the International Workshop "Socio-Environmental Dynamics over the Last 
12,000 Years: The Creation of Landscapes II $\left(14^{\text {th }}-18^{\text {th }}\right.$ March 2011)" in Kiel, 3. Universitätsforschungen zur prähistorischen Archäologie 207 (Bonn 2012).

- et al. 2010:-/N. Müller-Scheessel/J. Müller/K. Rassmann, Sozio-politische Organisationsstrukturen und zentrale Institutionen des spätneolithischen Visokobeckens in Zentralbosnien (5500-4500 v. Chr.). In: S. Hansen (Hrsg.), Leben auf dem Tell als soziale Praxis. Beiträge des Internationalen Symposiums in Berlin vom 26.-27. Februar 2007. Kolloquien zur Ur- und Frühgeschichte 14 (Bonn 2010) 189-213.

Horváth 1990: F. Horváth, Hódmezővásárhely-Gorzsa. Eine Siedlung der Theißkultur. In: Meier-Arendt 1990, 35-52.

- 2005 (2012): -, Gorzsa. Előzetes eredmények az újkőkori tell 1978 és 1996 közötti feltárásából [Gorzsa. Preliminary results of the excavation of the Neolithic tell between 1978-1996]. Hétköznapok Vénuszai. Hódmezővásárhely 2005 (2012), 51-83.

- 2015: -, Questions relating to the Proto-Tiszapolgár Period in South-Eastern Hungary. Main issues and present state of research. In: W. Schier/F. Draşovean (Ed.), The Neolithic and Eneolithic in Southeast Europe. New approaches to dating and cultural dynamics in the $6^{\text {th }}$ to $4^{\text {th }}$ Millenium BC. Prähistorische Archäologie in Südosteuropa 28 (Rahden/Westf. 2015) 297-318.

Isaakidou 2011: V. Isaakidou, Farming regimes in Neolithic Europe: gardening with cows and other models. In: A. Hadjikoumis/E. Robinson/S. Viner (Eds.), The Dynamics of Neolithisation in Europe. Studies in honour of Andrew Sherratt (Oxford 2011) 90-112.

Johnson 1982: G. A. Johnson, Organizational Structure and Scalar Stress. In: C. Renfrew/M. J. Rowlands/B. Segraves (Ed.), Theory and Explanation in Archaeology: the Southampton Conference (New York 1982) 389-421.

Kalicz 1995: N. Kalicz, Siedlungsstruktur der neolithischen Herpály-Kultur in Ostungarn. In: A. Aspes (Ed.), Settlement Patterns between the Alps and the Black Sea $5^{\text {th }}$ to $2^{\text {nd }}$ Millenium B.C. Verona -Lazise 1992. Memorie del Museo Civico di Storia Naturale di Verona (Ila serie) Sezione Scienze dell'Uomo 4 (Verona/Milano 1995) 67-75.

- 2001: -, Zusammenhänge zwischen Siedlungswesen und der Bevölkerungszahl während des Spätneolithikums in Ungarn. In: A. Lippert/M. Schultz/S. Shennan/M. Teschler-Nicola (Eds.), Mensch und Umwelt während des Neolithikums und der Frühbronzezeit in Mitteleuropa (Workshop Wien 1995) (Rahden/Westf. 2001) 151-170.

-/Raczky 1990a: -/P. Raczky, Berettyóújfalu-Herpály. Eine Siedlung der Herpály-Kultur. In: Meier-Arendt 1990, 117-140.

-/- 1990 b: -/-, Vergleichende C-14 Daten und Zeittabelle. In: Meier-Arendt 1990, 31-34.

Kuijt 2000: I. Kuijt, People and Space in Early Agricultural Villages: Exploring Daily Lives, Community Size, and Architecture in the Late Pre-Pottery Neolithic. Journal of Anthropological Archaeology 19, 1, 2000, 75-102.

Lazarovici 1991: G. Lazarovici, Grupul si Statiunea Iclod (Cluj-Napoca 1991).

- 2013: -, Despre sistemele de fortificatii neolitice din Transilvania si Banat (Partea I-A Fortificatiile neolitice). In: Peregrinari arheologice între estul şi vestul Europei. Studii în onoarea lui Tiberius Bader la aniversarea de 75 de ani/Archäologische Wanderungen zwischen Ost- und Westeuropa. Studien für Tiberius Bader zum 75. Geburtstag/Régészeti barangolások kelet és nyugat Európa között. Tanulmányok a 75 éves Tiberius Bader tiszteletére. Studii şi Comunicări Satu Mare. Seria Arheologie (Satu Mare 2013) 55-110.

Lee 2007: Y. K. Lee, Centripedal settlement and segmentary social formation of the Banpo tradition. Journal of Anthropological Archaeology 26, 2007, 630-675.

Leppard 2014: T. Leppard, Similarity and Diversity in the Prehistoric Colonization of Islands and Coasts by Food-Producing Communities. The Journal of Island and Coastal Archaeology 9/1, 2014, 1-15.

Link 2006: T. Link, Das Ende der neolithischen Tellsiedlungen. Ein kulturgeschichtliches Phänomen des 5. Jahrtausends v. Chr. im Karpatenbecken. Universitätsforschungen zur Prähistorischen Archäologie 134 (Bonn 2006).

Literski/Nebelsick 2012: N. Literski/L. D. Nebelsick, Katalog der Kreisgrabenanlagen und verwandten Tells der ersten Hälfte des 5. Jt. v. Chr. in Mittel- und Südosteuropa. In: F. Bertemes/ H. Meller (Eds.), Neolithische Kreisgrabenanlagen in Europa. Neolithic Circular Enclosures in Europe. Internationale Arbeitstagung 7.-9. Mai 2004 in Goseck (Sachsen-Anhalt)/ International Workshop $7^{\text {th }}-9^{\text {th }}$ May in Goseck (Saxony-Anhalt, Germany). Tagungen des Landesmuseums für Vorgeschichte Halle (Halle [Saale] 2012) 433-507.

Makkay 1982: J. Makkay, A magyarországi neolitikum kutatásának új eredményei: Az időrend és a népi azonosítás kérdései (Budapest 1982).

Marić et al. 2016: M. Marić/N. Mirković-Marić/B. Molloy/D. Jovanović/P. Mertl/L. Milašinivic/J. Pendić, New Results of the Archaeological Excavations on the site Gradište near Iđoš: Season 2014. Glasnik Srpskog arheološkog društva 32, 2016, 125-152.

Medović et al. 2014: A. Medović/R. Hofmann/Stanković Pešterac/ S. Dreibrodt/I. Medović/R. Pešterac, The Late Neolithic Settlement Mound Borđoš near Novi Bečej, Serbian Banat in a Multiregional Context - Preliminary Results of Geophysical, Geoarchaeological and Archaeological Research. Rad Muzeja Vojvodina 56, 2014, 53-77.

Meier-Arendt 1990: W. Meier-Arendt (Ed.), Alltag und Religion. Jungsteinzeit in Ost-Ungarn (Frankfurt a. M. 1990).

Mirković-Marić/Marić 2017: N. Mirković-Marić/M. Marić, Late Neolithic Tisza sites in the Serbian Part of the Banat. Archaeologiai Értesítő 142, 2017, 1-34.

Mischka 2012: C. Mischka, Late Neolithic Multiphased Settlements in Southern Transilvania: A Geophysical Survey and Test Excavation. In: Hofmann et al. 2012, 153-166.

Müller-Scheeßel et al. 2010a: N. Müller-Scheeßel/R. Hofmann/ J. Müller/K. Rassmann, Entwicklung und Struktur des spätneolithischen Tells von Okolište (Bosnien-Herzegowina) unter architektursoziologischen Gesichtspunkten. In: P. Trebsche/N. Müller-Scheessel/S. Reinhold (Eds.), Der gebaute Raum. Bausteine einer Architektursoziologie vormoderner Gesellschaften. Tübinger Archäologische Taschenbücher 17 (Münster 2010) 171-192.

- et al. 2010b: -/-/-/-, The Socio-Political Development of the Late Neolithic Settlement of Okolište/Bosnia-Hercegovina: Devolution by Transhumance? In: Kiel Graduate School "Human Development in Landscapes” (Ed.), Landscapes and Human Development: The Contribution of European Archaeology. Proceedings of the International Workshop "Socio-Environmental Dynamics over the last 12,000 Years: The Creation 
of Landscapes ( $1^{\text {st }}-4^{\text {th }}$ April 2009)". Universitätsforschugen zur Prähistorischen Archäologie 191 (Bonn 2010) 181-191.

Müller 2006: J. Müller, Demographische Variablen des Bosnischen Spätneolithikums - zur Frage der Bevölkerungsrekonstruktion im südosteuropäischen Neolithikum. In: N. Tasić/C. Grazdanov (Eds.), Homage to Milutin Garašanin (Belgrade 2006) 367-378.

- 2013: -, Demographic traces of technological innovation, social change and mobility: from 1 to 8 million Europeans (6000-2000 BCE). In: S. Kadrow/P. Wtodarczak (Hrsg.), Environment and subsistence - forty years after Janusz Kruk's „Settlement studies...”. Studien zur Archäologie in Ostmitteleuropa/Studia nad Pradziejami Europy Środkowej 11 (Rzeszów, Bonn 2013) 1-14.

- et al. 2011: -/R. Hofmann/N. Müller-Scheeßel/K. Rassmann, Zur sozialen Organisation einer spätneolithischen Gesellschaft in Südosteuropa (5200-4500 v. Chr.). In: S. Hansen/J. Müller (Eds.), Sozialarchäologische Perspektiven: Gesellschaftlicher Wandel 5000-1500 v. Chr. zwischen Atlantik und Kaukasus. Internationale Tagung 15.-18. Oktober 2007 in Kiel. Archäologie in Eurasien 24 (Darmstadt 2011) 81-106.

- et al. 2013a: -/-/-l/-, Neolithische Arbeitsteilung: Spezialisierung in einem Tell um 4900 v. Chr. In: A. Anders/G. Kulcsár (Eds.), Moments in Time: Papers presented to Pál Raczky on his $60^{\text {th }}$ Birthday. Prehistoric Studies 1 (Budapest 2013) 407-420.

- et al. 2013b: -/K. Rassmann/Z. Kujundžić-Vejzagić, Okolište Rekonstruktion spätneolithischer und frühchalkolithischer Siedlungsprozesse des zentralbosnischen Visokobeckens: Fragestellungen, Forschungsstrategien, Ergebnisse. In: J. Müller/K. Rassmann/R. Hofmann (Eds.), Okolište 1 - Untersuchungen einer spätneolithischen Siedlungskammer in Zentralbosnien. Universitätforschungen zur prähistorischen Archäologie 1 = Neolithikum und Chalkolithikum in Zentralbosnien 228 (Bonn 2013) 11-68.

Nandris 2007: J. Nandris, Adaptive Mediation in the FTN: The nature and rôle of the First Temperate European Neolithic. In: M. Spataro/P. Biagi (Eds.), A Short Walk through the Balkans: the First Farmers of the Carpathian Basin and Adjacent Regions. Proceedings of the Conference held at the Institute of Archaeology UCL on June $20^{\text {th }}-22^{\text {nd }}, 2005$. Società per la Preistoria e Protostoria della Regione Friuli-Venezia Giulia, Quaderno 12 (Trieste 2007) 11-23.

Neumann et al. 2014: D. Neumann/Z. Siklósi/R. Scholz/M. Szilágyi, Preliminary report on the first season of fieldwork in Berettyóújfalu-Szilhalom. Dissertationes Archaeologicae ex Instituto Archaeologico Universitatis de Rolando Eötvös nominatae 3/2, 2014, 377-403.

Ohlrau 2019 [forthcoming]: R. Ohlrau, Maidanets'ke: Development and Decline of a Trypillia "Mega-site" in Central Ukraine. Scales of Transformation in Prehistoric and Archaic Societies 7 (Leiden 2019 [forthcoming]).

Osztás et al. 2013 (2016): A. Osztás/I. Zalai-Gaál/E. Bánffy/ T. Marton/É. Á. Nyerges/K. Köhler/K. Somogyi/Z. Gallina/ C. B. Ramsey/E. Dunbar/B. Kromer/A. Bayliss/D. Hamilton/ A. Whittle, Coalescent community at Alsónyék: the timings and duration of Lengyel burials and settlement. Bericht der Römisch Germanischen Kommission 94, 2013 (2016), 179-282.

Parkinson 2006: W. A. Parkinson, The Social Organization of Early Copper Age Tribes on the Great Hungarian Plain. British Archaeological Reports International Series 1573 (Oxford 2006).
-/Gyucha 2012: -/A. Gyucha, Tells in Perspective. Long-Term Patterns of Settlement Nucleation and Dispersal in Central and Southeast Europe. In: R. Hofmann et al. 2012, 105-116. - et al. 2017: --/-/P. Karkanas/N. Papadopoulos/G. Tsartsidou/ A. Sarris/P. R. Duffy/R. W. Yerkes, A landscape of tells: Geophysics and microstratigraphy at two Neolithic tell sites on the Great Hungarian Plain. Journal of Archaeological Science: Rep. 19, 2017, 903-924.

Petrasch 2012: J. Petrasch, Ausgrabungspläne, die Bewohner bandkeramischer Häuser und die Sozialstruktur des mitteleuropäischen Frühneolithikums. In: M. Cladders/H. Stäuble/ T. Tischendorf/S. Wolfram (Eds.) Siedlungsstruktur und Kulturwandel in der Bandkeramik. Beiträge zur internationalen Tagung 'Neue Fragen zur Bandkeramik oder alles beim Alten?!' Leipzig, 23.-24. September 2010 (Dresden 2012) 53-67.

Porčić 2012: M. Porčić, Social complexity and inequality in the Late Neolithic of the Central Balkans: reviewing the evidence. Documenta Praehistorica 39, 2012, 167-183.

- et al. 2016: -/T. Blagojević/S. Stefanović, Demography of the Early Neolithic Population in Central Balkans: Population Dynamics Reconstruction Using Summed Radiocarbon Probability Distributions. PLOS ONE 11, 8, 2016, e0160832. https://doi. org/10.1371/journal.pone.0160832.

Raczky 2009: P. Raczky, Archaeological data on space use at tell-like settlement of the Tisza culture. New result from Öcsöd-Kováshalom. In: F. Draşovean/D. L. Ciobotaro/M. Ma ddison (Eds.), Ten years after: The Neolithic of the Balkans, as uncoverd by the last decade of research. Proceedings of the conference held at the museum of Banat on November $9^{\text {th }}-10^{\text {th }}, 2007$. Biblitheca Historica et Archaeologica Banatica 49 (Timişoara 2009) 101-124.

- 2015: -, Settlements in South-east Europe. In: C. Fowler/J. Harding/D. Hofmann (Eds.), The Oxford Handbook of Neolithic Europe (Oxford 2015) 235-253.

- 2018: --, A Complex Monument in the Making at the Late Neolithic Site of Polgár-Csőszhalom (Hungary). In: T. A. Bács/ Á. Bollók/T. Vida (Eds.), Across the Mediterranean - Along the Nile. Studies in Egyptology, Nubiology and Late Antiquity dedicated to László Török on the occasion of his $75^{\text {th }}$ Birthday, 1 (Budapest 2018) 15-60.

-/Anders 2010: -/A. Anders, Activity loci and data for spatial division at a Late Neolithic site-complex (Polgár-Csőszhalom: a case study). In: S. Hansen (Hrsg.), Leben auf dem Tell als soziale Praxis. Beiträge des internationalen Symposiums in Berlin vom 26.-27. Februar 2007. Kolloquien zur Ur- und Frühgeschichte 14 (Bonn 2010) 143-163.

-/Anders 2012: -/A. Anders, Neolithic enclosures in Eastern Hungary and their survival into the Copper Age. In: F. Bertemes/H. Meller (Eds.), Neolithische Kreisgrabenanlagen in Europa/Neolithic Circular Enclosures in Europe. Internationale Arbeitstagung 7.-9. Mai 2004 in Goseck (Sachsen-Anhalt) / International Workshop $7^{\text {th }}-9^{\text {th }}$ May 2004 in Goseck (Saxony-Anhalt, Germany). Tagungen des Landesmuseums für Vorgeschichte Halle (Halle [Saale] 2012) 271-309.

-/- 2014: -/-, Szentpéterszeg-Kovadomb. Egy késő neolitikus lelőhely tér-képei. In: A. Anders/C. Balogh/A. Türk (Eds.), Avarok Pusztái. Régészeti tanulmányok Lőrinczy Gábor 60. születésnapjára. Avarum Solitudines. Archaeological studies presented to Gábor Lőrinczy on his sixties birthday. Opitz Archaeologica 6 (Budapest 2014) 23-42. 
-/- 2016: -/-, Polgár-Bosnyákdomb, a Late Neolithic tell-like settlement on Polgár Island (NE Hungary). Preliminary results of the investigations. Folia Quaternaria 84, 2016, 99-122.

-/Sebők 2014: -/K. Sebők, The outset of Polgár-Csőszhalom tell and the archaeological context of a special central building. In: S. Forţiu/A. Cîntar (Hrsg.), ArheoVest Il1. In Honorem Gheorghe Lazarovici. Interdisciplinaritate în Arheologie 2 (Szeged 2014) 51-100.

- et al. 2015: -/A. Anders/K. Sebők/P. Csippán/Z. Tóth, The Times of Polgár-Csőszhalom Chronologies of Human Activities in a Late Neolithic Settlement in Northeastern Hungary. In: Hansen et al. 2015, 21-48.

- et al. 2010: -/I. Fodor/Z. Mester, Régészeti Kutatások Hajdúböszörmény-Pródi-Halmon. Archaeologiai Értesítő 135, 2010, 161-182.

-/Füzesi 2016: -/A. Fuzesi, Öcsöd-Kováshalom - A retrospective look at the interpretations of a Late Neolithic site. Dissertationes Archaeologicae ex Instituto Archaeologico Universitatis de Rolando Eötvös nominatae ser. 3/4, 2016, 9-42.

-/Sebők 2014: -/K. Sebők, The outset of Polgár-Csőszhalom tell and the archaeological context of a special central building. In: Forţiu/Cîntar 2014, 51-100.

Rassmann et al. 2014: K. Rassmann/R. Ohlrau/R. Hofmann/Carsten Mischka/N. Burdo/M. Y. Videjko/J. Müller, High precision Tripolye settlement plans, demographic estimations and settlement organization. Journal of Neolithic Archaeology 16, 2014, 63-95.

Reimer et al. 2013: P. J. Reimer/E. Bard/A. Bayliss/J. W. Beck/

P. G. Blackwell/C. Bronk Ramsey/P. M.

Grootes/T. P. Guilderson/H. Haflidason/I. Hajdas/C. Hatté/

T. J. Heaton/D. L. Hoffmann/A. G. Hogg/K. A. Hughen/

K. F. Kaiser/B. Kromer/S. W. Manning/M. Niu/R. W. Reimer/

D. A. Richards/E. M. Scott/J. R. Southon/R. A. Staff/

C. S. M. Turney/J. van der Plicht, IntCal13 and Marine13

Radiocarbon Age Calibration Curves 0-50,000 Years cal BP. Radiocarbon 55/4, 2013, 1869-1887.

Reingruber 2015: A. Reingruber, Absolute and Relative Chronologies in the Lower Danube Area during the $5^{\text {th }}$ Millennium BC. In: Hansen et al. 2015, 301-324.

Rosenstock 2009: E. Rosenstock, Tells in Südwestasien und Südosteuropa. Untersuchungen zur Verbreitung, Entstehung und Definition eines Siedlungsphänomens. Urgeschichtliche Studien 2 (Remshalden 2009).

Sahlins 1974: M. D. Sahlins, Stone age economy (London 1974).

Schier 2014: W. Schier, Der spätneolithisch-kupferzeitliche Tell von Uivar (Rumänien). Prospektionen und Grabungen 1998-2009. In: W. Schier/M. Meyer (Eds.), Vom Nil bis an die Elbe. Forschungen aus fünf Jahrzehnten am Institut für Prähistorische Archäologie der Freien Universität Berlin. Internationale Archäologie: Studia honoraria 36 (Rahden/ Westf. 2014) 17-36.

Shennan et al. 2013: S. Shennan/S. S. Downey/A. Timpson/ K. Edinborough/S. Colledge/T. Kerig/K. Manning/M. G. Thomas, Regional population collapse followed initial agriculture booms in mid-Holocene Europe. Nature Communications 4, 2013, 1-8.
Sherratt 1982: A. Sherratt, The Development of Neolithic and Copper Age Settlement in the Great Hungarian Plain, Part I: The Regional Setting. Oxford Journal of Archaeology 1, 1982, 287-316.

- 1983: -, The Development of Neolithic and Copper Age Settlement in the Great Hungarian Plain, Part II: Site Survey and Settlement Dynamics. Oxford Journal of Archaeology 2, 1983, 13-41.

Shishkin 1985: K. V. Shishkin, Planuvannja tripil's'kih poselen'za danimi aerofotozjomki. Планування трипільських поселень за даними аерофотозйомки. Arheologija 52, 1985, 72-76.

Siklósi 2013: Z. Siklósi, Traces of Social Inequality during the Late Neolithic in the Eastern Carpathian Basin. Dissertationes Pannonicae ex Instituto Archaeologico Universitatis de Rolando Eötvös nominatae Budapestinensis provenientes Ser. 6/3 (Budapest 2013).

Soudský 1962: B. Soudský, The Neolithic Site of Bylany. Antiquity 36, 1962, 190-200

Stanković Pešterac et al. 2014: T. Stanković Pešterac/R. Hofmann/ A. Medović/S. Dreibrodt/I. Medović, Multidisciplinary archaeological research at the late Neolithic site Bordjoš (Borjas) near Novi Bečej (Northern Serbia). Geoelectrical Prospection of a house. In: Forţiu/Cîntar 2014, 545-562.

Tasić et al. 2016: N. Tasić/M. Marić/D. Filipović/K. Penezić/ E. Dunbar/P. Reimer/A. Barclay/A. Bayliss/B. Gaydarska/ A. Whittle, Interwoven strands for refining the chronology of the Neolithic Tell of Vinča-Belo Brdo, Sebia. Radiocarbon 58, 2016, 1-37.

Marton/Oross 2012: T. Marton/K. Oross, Siedlungsforschung in linienbandkeramischen Fundorten in Zentral- und Südtransdanubien - Wiege, Peripherie oder beides? In: S. Wolfram/H. Stäuble (Eds.), Siedlungsstruktur und Kulturwandel in der Bandkeramik. Beiträge der internationalen Tagung „Neue Fragen zur Bandkeramik oder alles beim Alten?!” Leipzig, 23. bis 24. September 2010. Arbeits- und Forschungsberichte zur sächsischen Bodendenkmalpflege, Beih. 25 (Dresden 2012) 220-239.

Tripković 2009: B. Tripković, Kontinuiteti kuća i domaćinstava na središnjemu Balkanu od 5300. do 4600. g. pr. n. e. House(hold) continuities in the central Balkans, 5300-4600 BC. Opuscula Archaeologica (Zagreb) 33, 2009, 7-29.

Whittle et al. 2016: A. Whittle/A. Bayliss/A. Barclay/B. Gaydarska/ E. Bánffy/D. Borić/F. Draşovean/J. Jakucs/M. Marić/D. Orton/ I. Pantović/W. Schier/N. Tasić/M. V. Linden, A Vinča potscape: formal chronological models for the use and development of Vinča ceramics in south-east Europe. Documenta Praehistorica 43, 2016, 1-60.

\section{Supplemental materials}

Tab. S1: Borđoš, ${ }^{14} \mathrm{C}$-modelling, OxCal codes.

Tab. S2: List of used ${ }^{14} \mathrm{C}$ dates of multicomponent sites in the Tisza region. 